\title{
SIGNOS GLÍFICOS RELACIONADOS CON TLÁLOC EN LOS MURALES DE LA BATALLA EN CACAXTLA
}

\section{Marta Foncerrada de Molina}

Los signos glificos que aparecen en los murales de la batalla (taludes oriente y poniente del basamento de la subestructura del Edificio B y en el pórtico del Edificio A) en Cacaxtla (figura 1) tienen además de las cualidades estéticas que derivan de la calidad del diseño que los caracteriza y singulariza, una doble y significativa importancia.

En primer término, la presencia de connotaciones glíficas en los dos grandes conjuntos de pintura mural, revela su definitiva asociación con el significado o tema de las representaciones figurativas que los distingue; funcionan, dentro de cada uno de los esquemas compositivos, como transmisores de un mensaje específico, que debió ser asequible y comprendido en su momento histórico.

En segunda instancia e, íntimamente relacionado con lo asentado en el párrafo anterior, los glifos pintados en los muros de Cacaxtla, señalan, en su variedad, la confluencia de sistemas de escritura de distinta procedencia espacio-temporal: Teotihuacan, Monte Albán, Xochicalco y Tula. Este pluralismo epigráfico pone de manifiesto la peculiar situación histórica y artística del Epiclásico en el Altiplano Central generada por la caída de Teotihuacan hasta la instalación del poderío tolteca (ca S. VIII a X D.C.). A este incierto $\mathrm{y}$, a la vez, dinámico periodo durante el cual se gesta la reestructuración político-religiosa del Altiplano Central, pertenece el florecimiento de sitios como Xochicalco en Morelos y Cacaxtla en el suroeste de Tlaxcala. En Cacaxtla, el arte pictórico, integrado a la arquitectura, se expresó con inusitada audacia creativa.

Sorprende, por otra parte, la ausencia de glifos mayas inscritos en los polícromos murales de Cacaxtla; el realismo naturalista, centrado en la representación de la imagen del hombre, que los singulariza, indica una indiscutible vinculación estilística y temática con el arte figurativo maya. Esto se confirma y complementa por el registro de personajes cuyos rasgos físicos, atavío e insignias los identifican, étnica y culturalmente, con esta vasta región de Mesoamérica.

En mi opinión, los murales documentan básicamente, la relación de Cacaxtla con la frontera occidental maya, es decir, la que comprende el área del Usumacinta, desde la cuenca del Río Pasión hasta su desembocadura en Potonchán (Frontera, Tabasco) en la costa del Golfo. ${ }^{1}$

I. Jiménez Moreno, Wigberto El Enigma de los Olmecas (1942). Reimpreso por I I A., 1976, UNAM. Ibid: Síntesis de la Historia Pre-Tolteca de Mesoamérica en El Esplendor del México Antiguo Vol 2, 1959 Centro de Investigaciones Antropológicas, México Armillas, Pedro: Los Olmecas Xicalanca y los Sitios Arqueológicos del Sureste de Tlaxcala, $R$. M. E. A VII, 1946. 
De esta región proceden los olmecas xicalancas (Jiménez Moreno, 1942:127, 128) quienes en el siglo IX conquistan Cholula $y$, en su afán expansionista, se extienden por el valle poblano-tlaxcalteca. En el suroeste de Tlaxcala, Cacaxtla se convierte en floreciente y estratégico reducto olmeca xicalanca.

La expresión artística del sitio revela el vivo contacto que el grupo olmeca xicalanca tuvo con la cultura maya durante el Clásico Tardío. Este contacto lo auspició, en gran medida, la actividad comercial de Teotihuacan con la Costa del Golfo. La tradición cultural de la Metrópoli dejó su impronta tanto en los mayas locales como en los itinerantes olmeca xicalancas, comerciantes y guerreros de profesión.

La propicia circunstancia histórica determinó el transitorio periodo de auge olmeca xicalanca en un área importante del Altiplano Central. Cacaxtla, da fe de ello. La arquitectura palaciega del sitio construido sobre un cerro, la iconografía de sus murales, el relieve de barro integrado a los edificios y la cerámica, reflejan la presencia indiscutible de la influencia maya y teotihuacana tamizada con la de otras regiones y tradiciones mesoamericanas, la que se llevó a cabo, sin embargo, con el sello de una original y excepcional creatividad artística local.

Apunto aqui, de manera esquemática, estas ideas, consciente de que requieren mayor y más detallada aportación de datos. Rebasan lo que me he propuesto tratar en este artículo, por lo que me concreto a exponerlas.

El presente trabajo intenta esclarecer parte del código epigráfico vinculado, ideográficamente, a Tláloc como deidad guerrera. Estos signos y la imagen del dios de la lluvia señalan, a mi juicio, la pervivencia de la tradición cultural tardía teotihuacana en la iconografía del muralismo en Cacaxtla.

Me limito a abordar este problema, a la luz de las representaciones arriba mencionadas, en los taludes oriente y poniente del basamento sur del Edificio $\mathrm{B}$, los que contienen los murales de la batalla.

Estos murales preceden en el tiempo a los del pórtico del Edificio A. El lapso que separa a uno y otro conjunto mural es, aproximadamente, de 50 a 100 años. A mi juicio, la ubicación cronológica de los taludes pintados fluctúa entre 750 y 800 D.C., mientras que los del pórtico, corresponderian a un periodo que se traslapa con los inicios de la época tolteca, es decir, entre 850 y 900 A. $\mathrm{C}^{2}$

Antes de entrar en materia, me referiré brevemente a los temas tratados en la decoración pictórica de las dos estructuras arquitectónicas ya menciona-

León Portilla. Miguel: Ion Olimera en Chalo Amaqumecan. Centro de Estudios de Bernardino de Sahagün 1. C: Amecameca, Edo de México, 1980. Muñoz Camargo, Diego: Historia de Tlarcala. Publicada y anotada por Alfredo Chavero Oficina Tipo de la Sría de Fomento, 1892, México

". Jiana López de .I y Daniel Molina: (acavla Guía Oficial, 1 N A.H 1980, México Ibid: Informes inéditos sobre excavación arqueológica de Cacaxtla 1976-1980. Archivo Técnico del IX. I.H. Molina, Daniel: Consideraciones sobre la Cronologia de Cacaxtla Actas del XLII Congrnw Inlmatumal de tmumam. Vol VII Paris, 1976 
DOI: http://dx.doi.org/10.22201/iie.18703062e.1982.50\%20Tomo\%201.1135

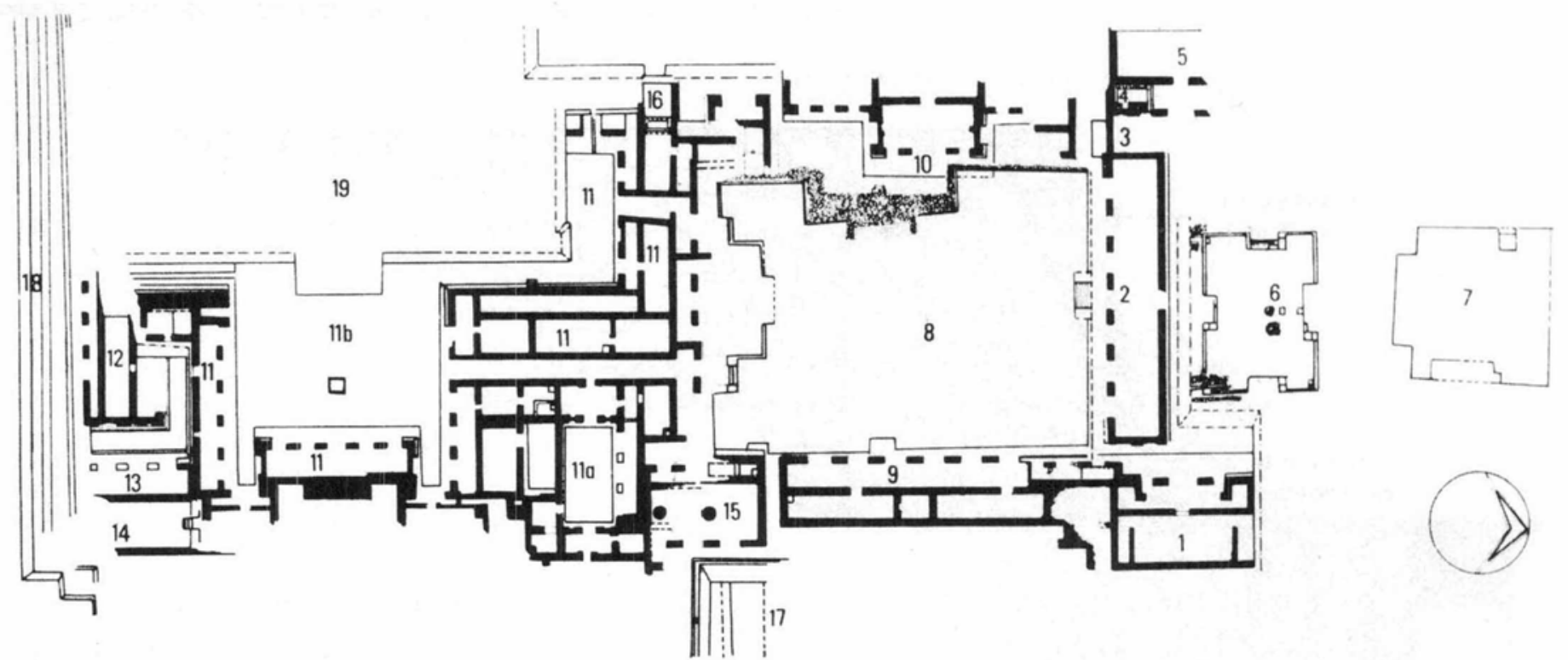
1. Edificio $A$ o de las Pinturas
3. Pasillo de los Tableros
4. Las "Conejeras"
5. Edificio $C$
6. Patio Hundido

7. Monticulo $Y$

8. Plaza Norte

9. Edificio D

10. Edificio $E$

11. El Palacio

11a. Patio de los Rombos

11b. Patio de los Altares

11c. Pórtico A

12. Edificio $F$

16. La Celosia

13. Pórtico $F$

17. Taludes del Este

Plano de la nomenclatura utilizada para las distintas estructuras excavadas en lo alto del Gran Basamento.

Figura 1. Plano de Cacaxtla. Edificio A y B marcador con los números 1 y 2 Guía Oficial I.N.A.H. (Cortesía del I.N.A.H.) 


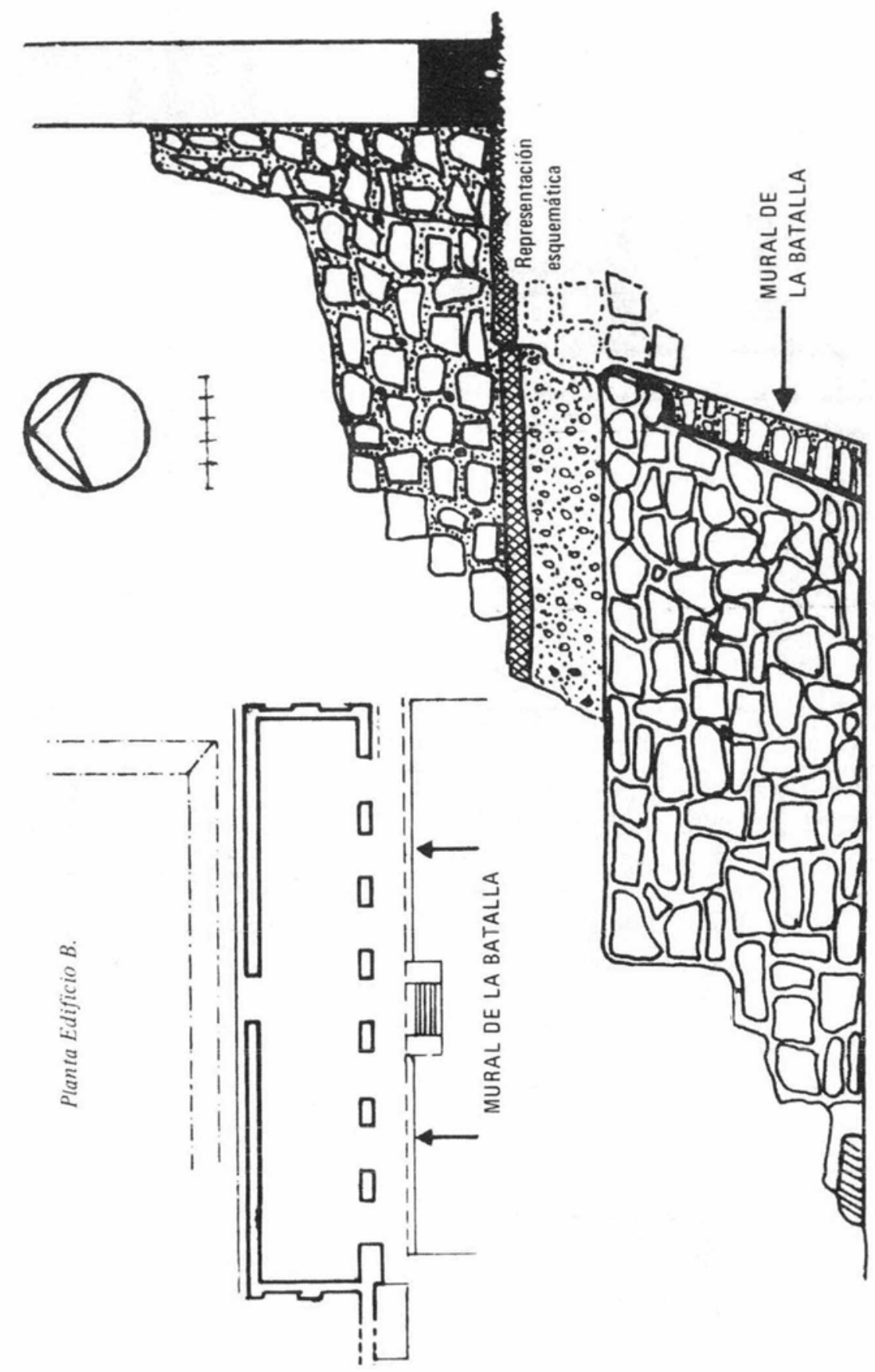

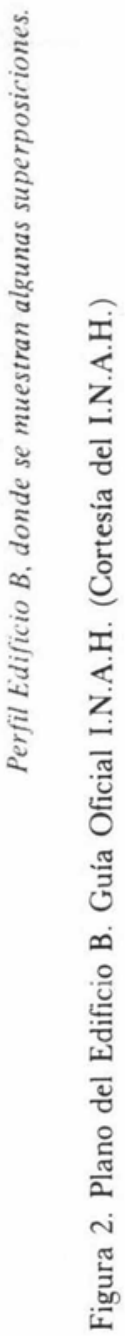


das. La pintura mural, en uno y otro, tiene una interesante y sutil relación de contenido, la que podría reducirse a dos términos: prólogo y epílogo de un suceso histórico que se documentó en forma descriptiva en los dos taludes y se concluyó, de manera simbólica y apoteósica, aunque no inmediata, en el Edificio A.

Cabe señalar aquí, que el conjunto pictórico del Pórtico, corresponde a un periodo en el cual los taludes de la batalla yacían ocultos a la vista de los habitantes de Cacaxtla. Cubiertos cuidadosamente por una fina capa de tierra, de ahí su extraordinaria preservación, formaban parte del núcleo de un nuevo basamento más amplio construido para sustentar el alargado edificio porticado (b), contemporáneo al Edificio A (figura 2).

\section{Los Murales}

La secuencia figurativa que decoró los taludes oriente y poniente, divididos por una escalera central, muestra una sangrienta escena de batalla en la que se plasmó con dinámico realismo natur alista, el triunfo y la derrota de los grupos claramente diferenciados (figuras 3, 4, 5, 6, 7: T.O. 8, 9, 10, 11: T.P.).

El tema bélico comprende la representación de 47 figuras humanas en variadas posturas, formas de atavio, armas y glifos. La precisa y definida combinación de estos elementos logra transmitir el mensaje de triunfo y de derrota que se desarrolla a lo largo de los dos inclinados paramentos; sobre un fondo azul claro, la audaz organización de imágenes humanas proyecta vitalmente su dramática y combativa interacción.

Se advierten esquemas compositivos semejantes en uno y otro talud y también, variantes. El genio artístico evitó la repetición estereotipada de recursos expresivos. Estas variantes compositivas e iconográficas y la diversidad en el trazo lineal y el mayor o menor equilibrio formal en el manejo del espacio pictórico, indican la posible intervención de varios artistas en la ejecución de los murales.

Las secciones mejor preservadas y más logradas artísticamente son las más próximas a la escalera central. El talud oriente, es, curiosamente, más largo que el poniente y, a diferencia de éste, marca con doble línea, el espacio donde concluye el variado despliegue de imágenes y glifos ricamente coloreados. En el extremo poniente del otro talud no ocurre lo mismo; su longitud menor, la ausencia de un trazo que marque el límite del esquema pictórico y su parcial destrucción y erosión impiden una objetiva valoración estética y de significado respecto a esta parte del mural. Sin embargo, los elementos aún visibles, permiten afirmar que el contenido, aunque probablemente no la mano que lo ejecutó, corresponde al sentido que el programa pictórico se propuso dejar impreso en los dos taludes.

El recuento de guerreros victoriosos y derrotados da el saldo siguiente: 13 triunfadores y 14 derrotados en el talud oriente y 11 vencedores contra 9 vencidos en el talud poniente. 
La victoria le corresponde a guerreros (¿olmeca xicalancas teotihuacanizados?) de tosco perfil y agresiva boca abierta que muestra los dientes. Estos portan prendas o insignias de jaguar, banda ceñida a la cabeza con adorno circular al frente y sobre la coronilla, plumas cortas y flores. El adorno circular, en varios de ellos, es claramente una concha de mar, lo que podría ser un símbolo de su origen costeño. Su agresivo y triunfalista belicismo se manifiesta en las largas lanzas y afilados cuchillos que apuntan y penetran en los abatidos cuerpos del desvalido grupo vencido.

La derrota está expresada, dramáticamente, en personajes de claros rasgos físicos mayas quienes traen la cabeza semicubierta por un yelmo de ave del que cuelgan largas plumas. Grandes y profundas heridas dejan las vísceras de algunos de ellos, al descubierto; la sangre corre en abundancia de sus lacerados cuerpos desnudos. A pesar de que las señales de agonia, captura, sacrificio y muerte se manifiestan, indistintamente, en los vencidos, sus cuerpos conservan además del tocado, las joyas de piedra y otros adornos de tela. Ello indica la deliberada intención artística de mostrar el poder económico y el alto rango social de los derrotados. Lo anterior se confirma plenamente al observar, en uno y otro talud, dentro de la sección más cercana a la escalera central, la representación de los dos dirigentes del contingente maya Estos aparecen en posición erecta con el cuerpo de frente y el rostro de perfil, regiamente ataviados de manera similar, aunque no idéntica.

La señal de derrota está también registrada en ambos casos, con recursos expresivos distintos: en el talud oriente, la punta de una lanza, traspasa la mejilla del dignatario. En el talud poniente, el caudillo maya tiene los brazos sobre el pecho y las dos manos juntas parecen estar atadas; además, un adversario a su derecha apunta amenazadoramente al torso del personaje; casi podría decirse que en el instante previo a que ésta lo atraviese.

En contraste con el numeroso despliegue de figuras humanas que en plena acción bélica, se mueven dentro del inclinado espacio rectangular de los taludes, los murales del Pórtico del Edificio A destacan por la parquedad figurativa de la ejecución pictórica, la que decoró, respectivamente, coñ unã sỏà imagen humana, los dos muros posteriores y las jambas adyacentes

En términos generales, puede afirmarse que la decoración pictórica del Pórtico del Edificio A significa la sublimación del cruento evento bélico registrado, años atrás, como un documento histórico que, con original creatividad artística y sutil maestría técnica, había descrito la agresiva confrontación de dos grupos humanos y la secuela de triunfo y de derrota de uno sobre el otro. Lo sucedido entonces, a pesar de no ser ya visible, pervivía en la memoria de los heterogéneos olmecas xicalancas, señores de Cacaxtla, quienes en el mural de la batalla, representan a los guerreros victoriosos.

Por complejas razones de tipo político y religioso convino a la estructura del poder en Cacaxtla, darle impulso, a un programa muralista que dejase plasmada en el pórtico del Edíficio A, no sólo la amnistía, sino idéntica jerarquía a los vencedores y a los vencidos en la escena de la batalla pintada en un periodo más temprano (figuras $12,13,14,15$ ). 
Es asi como los derrotados mayas aparecen en el muro suroeste, personificados por un héroe divinizado dotado de la misma categoría mítica que la del personaje que ocupa el muro noroeste, quien representa por sus rasgos físicos y atavío a los agresivos guerreros que, en desigual encuentro, años atrás, avasallaron a sus rivales mayas.

En términos generales, puede decirse que las imágenes del Hombre Pájaro maya y el Hombre Jaguar olmeca xicalanca con sus respectivos animales míticos: la serpiente emplumada y el jaguar serpentino, y las dos figuras humanas de las jambas que parecieran fungir como acompañantes de uno y de otro, los unifica un mismo contexto simbólico: fecundidad, abundancia de la tierra, vida nueva y compartido poder político religioso.

La violencia esencial de la guerra, el destructivo poder de la lanza, la sangre del hombre derramada, el sacrificio y la muerte en batalla, los transformó el pensamiento mítico religioso en agua, en flores y grano, en riqueza y autoridad humana sobrenatural.

\section{Los signos glificos}

En los taludes de la batalla varios signos glificos se distribuyen y repiten a lo largo de la composición pictórica. Se representaron generalmente, como elementos aislados, repartidos asimétricamente en los espacios vacios, relativamente pequeños que quedan entre las figuras humanas contendientes.

Los glifos, en ocasiones, forman parte del atavío de los guerreros victoriosos lo que señala una diferencia básica respecto a la ausencia total de los mismos en el atuendo del grupo adversario con rasgos físicos mayas.

Por su posición, algunos glifos aparecen como recursos gráficos que connotan el nombre calendárico del personaje, es decir, el signo acompañado de numerales; éstos últimos, invariablemente, en forma de disco. En otros casos, el glifo, al convertirse en adorno de la suntuaria, cumple la función de señalar el rango del guerrero. Estos glifos nominales y de status militar le confieren identidad personal y destacan la importancia de ciertos vencedores en contraste con el anonimato de todos los integrantes del grupo agredido.

La función que cumplen otros glifos es de orden más general; su repetida representación en el contexto figurativo significa la insistente alusión a la secuela de sangre, sacrificio y muerte que resulta de la esencial agresividad del suceso bélico, dramáticamente descritos en la extensa secuencia figurativa.

A continuación, expongo algunas reflexiones sobre el más importante de estos últimos: el glifo "corazón o sangre" y su relación con ei Tláloc de la guerra y el símbolo del año teotihuacano, dos motivos iconográficos que revelan la difusión de la tradición simbólica de la Metrópoli en el tiempo y el espacio mesoamericanos. ${ }^{3}$

3. Caso, Alfonso Los Calendarios Prehispánicos, I. I. H, 1967 UNAM. Kubler, George: The Iconography of the Art of Teotihuacan. Studies in Pre-Columbian Art Archaeology No 4, Dumbarton 


\section{Glifo Corazón o Sangre}

El glifo tuvo una larga trayectoria temporal en el Altiplano Central (figura 16). Su origen se remonta a Teotihuacan, se perpetúa en Xochicalco y persiste hasta el Posclásico en Tula (Caso, 1967, p. 175). Su aparición en los murales de la batalla en Cacaxtla representa una variante más, la que, por la similitud en el diseño, lo relaciona más directamente con Xochicalco, según fue plasmado en la cara principal de la Estela 3 de este sitio (figura 17)

En Cacaxtla, el glifo se caracteriza como un rojo medallón moldurado de cuyo nivel inferior penden tres grandes y alargadas gotas de sangre En el centro del medallón se inscribe el diseño oblongo que, esquemáticamente, representa el corte longitudinal de un corazón humano; dos pequeñas bandas lo cruzan en su interior, el que se pintó de rojo o de azul; las bandas tienen los mismos colores y se aplicaron, indistintamente, para contrastar con el pigmento que les sirve de fondo (figura 18).

La repetida representación del glifo en los taludes de la batalla en Cacaxtla confirma su decisiva connotación de sangre (figuras $19,20,21,22$ ).

Lo anterior se comprueba plenamente en la figura 21 del talud oriente: un borbotón y numerosos hilos de sangre brotan del glifo, expresivamente colocado en la herida del vientre del lacerado cuerpo yacente de la víctima (figura 23).

Permanecen aun visibles cuatro de estos glifos en el talud oriente y cinco en el poniente. Lo más probable es que se hubiese representado un número mayor, principalmente en el nivel superior de ambos murales. La mayoría de ellos se conservan, total o parcialmente, en esta sección, la que, desafortunadamente, resultó la más dañada cuando se construyó el nuevo basamento que habría de cubrir ambos taludes.

El glifo se representó, generalmente, como un signo epigráfico aislado y colocado entre los personajes sobre el espacio azul del fondo. Una excepción es el que aparece en el cuerpo del maya vencido, al que hice ya referencia y otra, cuando parece deslizarse sobre las plumas que cuelgan del escudo redondo del personaje 30 en el talud poniente (figura 24).

Otra importante variante del glifo "corazón o sangre", se encuentra en el talud oriente, frente al rostro del personaje 10 (figura 25). En este caso, forma parte de un conjunto de tres glifos, dispuestos en secuencia horizontal. Se encuentra colocado en el extremo posterior del texto con todos los elementos que lo caracterizan, los cuales son, posiblemente, los mismos que conforma-

Oaks, 1967, Washington. Teotihuacan: Yl Mesa Redonda Sociedad Mexicana de Antropología, 1972,

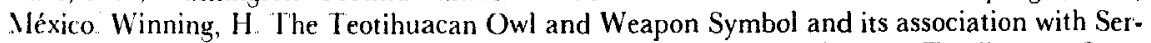
pent llead at Kaminaljuyu. Ciuat tmertan tmiquity. Vol XIV no 2, 1948. Teotihuacan Symbols: The Reptile's Eye Glyph Ethmo. Vol 26, INo 3. Stockholm 1961 Winning, H "Semejanzas entre las ligurillas de Jaina y de Teotihuacan" Sobretiro de "La Revisla Mexicana de Esludios Antropultoysu": Tomo XX1, México, 1967. Winning, H A. Symbol for Dripping Water in the leothuacan Culture El Wétuo Intiguw Vol. VI México 1974 a Winning, H Der Netzjaguar in Ieotihuacan: Eine Ikonographische Unterscuchung. Baesskr-Archiv. Band XVI Berlín, 1968. 
ron otros que aparecen parcialmente destruidos. El signo que le sigue es el que denomino "triple moño" y el otro, más próximo a la cabeza del guerrero, el 2 turquesa. Los dos primeros y la efigie de Tláloc aparecieron en la afortunada y última limpieza del mural.

Los elementos que distinguen a esta variante del glifo corazón o sangre en Cacaxtla, de su representación en otros sitios y, aun del propio Xochicalco, son los siguientes: sobre el borde superior del marco, se insertan cuatro blancos y simétricos dientes humanos los que salen de una esquemática boca azul de redondeado contorno. Un disco también de color azul, decorado con líneas negras que se entrecruzaron en el centro, se apoya y flexiona el nivel superior de la abierta fauce (figura 26).

La boca abierta que muestra los dientes representa, a mi juicio, la boca de Tláloc y simboliza el agresivo canto o grito del guerrero en acción; como tal, adjetiva la idea del corazón que sangra contenida en el glifo al cual se superpone.

Por último, el disco no cumple, en este caso, una función numérica; en mi opinión, su significado de turquesa callifica a la guerra como un evento precioso, sagrado. El empleo del color azul verifica estos atributos y confirma una vez más, el sentido místico y trascendente que la guerra tuvo en las culturas del Altiplano, desde Teotihuacan, donde posiblemente se originó, hasta la época mexica.

El glifo se integra al atavío de los guerreros victoriosos como un adorno que intensifica la personalidad agresora del personaje que los porta. En las figuras 3 y 29 del talud oriente y poniente, respectivamente, estos glifos penden del ancho y elaborado cinturón de uno y otro personaje. En ambos casos, el glifo, aunque similar, no es de idéntico diseño. Del cinturón del guerrero en el talud poniente cuelgan tres de color rojo rematados por una sola gota de sangre. El corazón humano, en este caso, se singulariza por contener en la parte superior la representación minúscula de un ojo, elemento que se repite en otros de los gilifos representados como signos aislados. A diferencia de su contraparte en el talud oriente, el contorno del glifo y las bandas que lo cruzan son azules mientras que el marco y su triple remate de gotas colorearon de rojo a los cuatro signos, divididos simétricamente por el triple nudo azul que recoge los tres dobleces de la larga tira del máxtlatl (figuras. 27 y 28).

Además de las características arriba señaladas, el cinturón del personaje en el talud oriente, ostenta en el costado, el mascarón de perfil de Tláloc cuyos aserrados colmillos parecieran clavarse en el abierto y ensangrentado pico de ave, parte del yelmo del mutilado cuerpo del maya que yace bajo este guerrero coyote.

El diseño acuático en el interior del glifo "corazón o sangre" del guerrero coyote, sugiere, sutilmente, su asociación con los atributos acuáticos de Tláloc, relación que no está presente en los que porta el guerrero del talud poniente.

El glifo aparecen también como adorno de rodilla; tal es el çaso del guerre- 
ro 7 en el talud oriente al que la cubre una ancha banda amarilla moteada de rojo adornada con gotas de sangre; ésta se cierra al frente con dos lazos y sendos nudos rojos de los que pende el glifo pintado del mismo color (figura 29).

La versión más simplificada de este signo epigráfico consiste en la exclusiva representación de las gotas de sangre. En su forma triple, más característica aparece bajo nudos, como el que ata la garra del chaleco de jaguar que cubre al guerrero 7 y el del máxtlatl del personaje 13 en el talud oriente. De la rodillera de tela de éste último cuelgan, en hilera, una serie de gotas (figuras $30 \mathrm{y}$ 31).

En párrafos anteriores, me referí al único caso en el que el glifo "corazón o sangre" forma parte de un mínimo texto constituido por tres glifos dispuestos horizontalmente en el nivel superior del talud oriente.

Esta secuencia reviste particular interés por su afortunada preservación en una de las secciones (oriente) del doble conjunto mural, cuya variada riqueza iconográfica la convierte en importante clave visual, que permite aproximarse a la comprensión del significado cultural y artístico contenido en el documento pictórico.

La totalidad del área que contiene los tres glifos está constituida por la dinámica y bien lograda composición de dos figuras humanas: la erecta del guerrero agresor y la semisentada de su moribunda víctima (personajes $10 \mathrm{y}$ 11).

El elemento iconográfico que le confiere a esta pareja de contendientes un carácter excepcional dentro de la totalidad del conjunto pictórico de ambos taludes, consiste en la insospechada representación de un Tláloc efigie cuya personalidad guerrera es, en este caso, indiscutible (figura 32).

El dios surge como portaestandarte, tras el gran escudo redondo del guerrero ataviado con elaborado chaleco de jaguar quien blande una larga lanza que remata en afilada punta y en cuyo fuste se insertó un átlalt.

El pintor dejó claramente visibles el rostro y tocado de Tláloc, parte de su torso y el brazo flexionado que sostiene en la mano un palo curvo (posiblemente el escudo visto de perfil). Finas y afiladas puntas de obsidiana fluyen de la mano del dios en dirección al penacho de abundantes y oscilantes plumas con que remata el tocado de cabeza de pájaro del moribundo y enjoyado personaje maya sobre cuyo sangrante muslo pone un pie, en desafiante posición de salto, el guerrero de Tláloc (figura 33).

En el bélico contexto de los murales, la presencia de la imagen completa de Tláloc, revela su clara asociación con la guerra y confirma la doble naturaleza que el dios de la lluvia tuvo desde Teotihuacan (Pasztory, 1974).

El rostro de perfil del Tláloc efigie del Cacaxtla se caracteriza por el grueso y rígido labio superior que en la comisura se voltea hacia arriba en forma de voluta; colmillos del mismo tamaño y una parte de la ondulante lengua bífida que cae sobre el mentón completan el diseño bucal. Este conjunto, corresponde al rasgo fisonómico, diagnóstico que Pasztory (1974:9) señala para diferenciar, en la iconografía teotihuacana, al Tláloc Jaguar militante y viajero del 
Tláloc Cocodrilo, exclusivamente asociado a la tierra y al agua, el que muestra dientes y largos colmillos bajo un labio superior que se voltea hacia abajo $y$, generalmente, una flor que reemplaza la lengua bífida de la otra acepción del dios de la lluvia.

Es importante poner de relieve que la expresión humanizada y realista del arte pictórico de Cacaxtla, muestra la asociación del Tláloc de la guerra con el jaguar de manera directa; está claramente integrada al contexto descriptivo y naturalista de programa pictórico. El caso más obvio es precisamente al que he hecho referencia en párrafos anteriores. La piel de jaguar completa con las garras y la feroz cabeza del felino, finamente dibujadas, rematan el chaleco del guerrero que trae a Tláloc como portaestandarte. En Teotihuacan esta asociación se dio en forma más simbólica. Acorde con la tradición artística de la Metrópoli, los atributos agresivos del dios y del felino formaron parte de un imaginativo vocabulario de sangre y de muerte que ocultó el acento dramático que estos términos implican en relación a la vida humana.

Volviendo a Cacaxtla, puede afirmarse que, aun cuando la efigie de Tláloc aparece representada una sola vez, es tambiẻn la única deidad presente en todo el contexto pictórico de ambos murales. Esto permite suponer que es el dios bajo cuyo patrocinio los guerreros vencedores aniquilan al grupo contrario.

Lo anterior se confirma por el repetido empleo de la piel de jaguar como parte del atavío que, indistintamente, pero de manera exclusiva portan la mayor parte de los guerreros victoriosos.

Además, rasgos de Tláloc que fungen como elementos emblemáticos y confirman la actividad guerrera del dios, distinguen a dos importantes personajes: el 3, en el talud oriente y el 29 en el talud poniente (figuras 34 y 35). Frente a la boca de uno y otro, aparece en un azul intenso el vigoroso trazo del labio superior de Tláloc Jaguar; de su abierta fauce salen tres largos y afilados dientes de los que fluye sangre. Un diseño excéntrico de color oscuro, se desplanta del nivel superior del labio del dios. Este conjunto simbólico, yuxtapuesto al rostro de perfil de los dos guerreros, pareciera indicar, como lo señala la expresiva boca abierta de ambos, que se simboliza así el canto o grito de guerra de Tláloc. En este caso, se trata de una original variante de la vírgula de la palabra tan frecuentemente utilizada en la pintura mural Teotihuacana.

El patronazgo de Tláloc se hace más evidente aun, en el guerrero 3 del talud oriente, por el esquemático y agresivo perfil del dios que ornamenta su ancho y elaborado cinturón.

La vinculación cultural de Cacaxtla con Teotihuacan se hace patente en la presencia de motivos iconográficos procedentes de la Metrópoli los que son privativos del grupo vencedor en los murales de la batalla. Es este grupo el que integra a los guerreros jaguar, afiliados al Tláloc militante teotihuacano. Asociado a ellos, aparece, invariablemente, el glifo corazón o sangre de indudable raigambre teotihuacana. 
Corrobora lo anterior, el hecho de que los personajes que entonan el canto u oración del Tláloc de la guerra ( 3 en Talud E y 29 en Talud P) portan el símbolo del año teotihuacano como insignia de rango que ornamenta la banda ceñida a la cabeza que los distingue como guerreros victoriosos. En este caso, el símbolo, pintado de azul, cuelga, invertido, del nudo que amarra en la parte de atrás a la banda.

Cabe recordar que el símbolo del año forma parte del tocado de numerosas representaciones de guerreros en Teotihuacan durante las fases terminales de la Metrópoli. Es en ésta donde se advierte ya la existencia de órdenes militares, entre los que pueden consignarse los de Tláloc-Jaguar, Coyote y Águila.

Puede afirmarse que en Cacaxtla, pervive con singular vigor, la tradición guerrera del Tláloc-Jaguar en las representaciones del grupo victorioso.

Las reflexiones anteriores señalan la profunda involucración de los olmecas xicalancas con la tradición cultural tardia teotihuacana. Esta sugiere las siguientes proposiciones:

1) el asentamiento parcial del grupo olmeca-xicalanca en Teotihuacan como comerciante y guerrero que facilitó el contacto de la Metrópoli con la Costa del Golfo y la región occidental maya

2) Teotihuacan promovió el culto al Tláloc de la guerra, como deidad local itinerante. Como tal, acentuaron los atributos bélicos del dios en detrimento de sus tradicionales cualidades benéficas, relacionadas con la lluvia y la abundancia de la tierra.

La advocación guerrera de Tláloc fue la que absorbieron los olmecas xicalancas costeños. La caída de Teotihuacan propició la migración expansionista de este grupo hacia los valles de Puebla y Tlaxcala. Es el Tláloc Jaguar, el Tláloc de la guerra, el que llevan consigo; su imagen y símbolos asociados, quedaron plasmados en los taludes de la batalla. Dan testimonio de una tradición político religiosa compartida con Teotihuacan. Tradición que, a mi juicio, intervino, en alguna medida, en el desarrollo de la expresión militarista del arte maya del área del Usumacinta y afectó profundamente el proceso de desarrollo histórico de la misma durante las etapas finales del Clásico Tardío de la región. Esto alude al interesante tema de los putunes y su acción transformadora en la cultura maya tardía, ${ }^{4}$

El tema de este artículo ha dejado fuera, no por inexistentes, las considera-

4. Chadwick Robert: The Olmeca Xicallanca of Teotihuacan: a preliminary study Mesoamenoan Notes 7-8. Dept of Anthropology. University of the Americas, 1966, México Millon, Clara Painting Writing and Polity in Teotihuacan, México American Antiquity 38: 294-314, 1973 Pasztory Esther; The iconography of the Teotihuacan Tláloc. Studies in Pre-Columbian Art and Archaeology No. 15, 1974, Dumbarton Oaks, Washington. Kubler, George: Eclecticism in Cacaxtla Third Palenque Round Table Part 2, 1978. Foncerrada de Molina, Marta: The Cacaxtla Murals: An Example of Cultural Contact? Iberoamerikaneschen Archiv, 1978, Berlin, Ibid. Mural Painting in Cacaxtla and Teotihuacan, Cosmopolitism. Third Palenque Round Table. Part 2, 1978 Univer sity of Texas Press Austin and London Thompson J Eric Maya Hestory and Relegion. University of Oklahoma Press; 1970 Norman, Okla 
DOI: http://dx.doi.org/10.22201/iie.18703062e.1982.50\%20Tomo\%201.1135
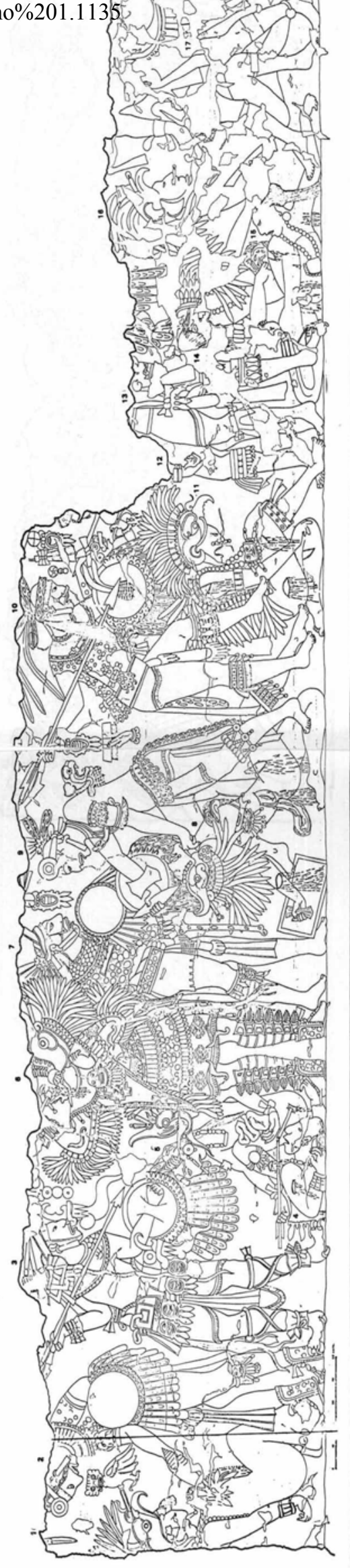


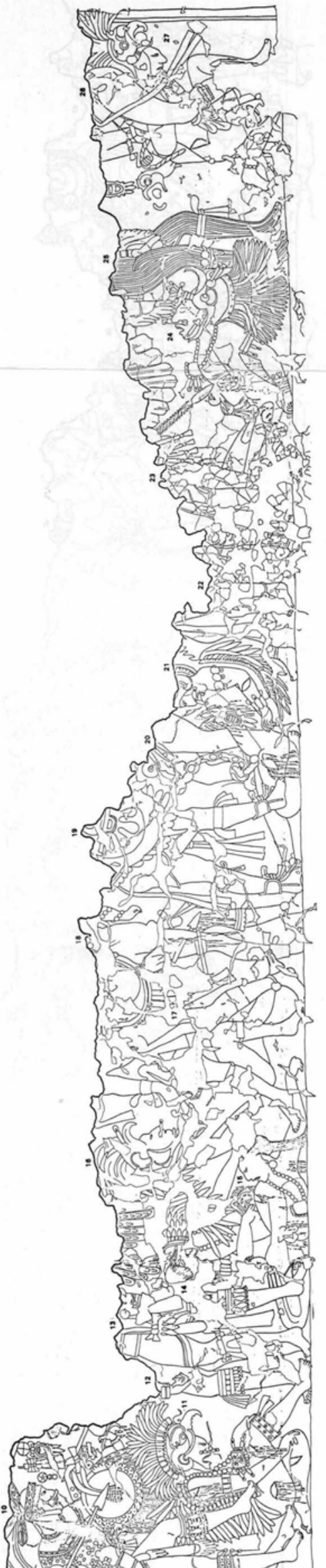


DOI: http://dx.doi.org/10.22201/iie.18703062e.1982.50\%20Tomo\%/201.1135

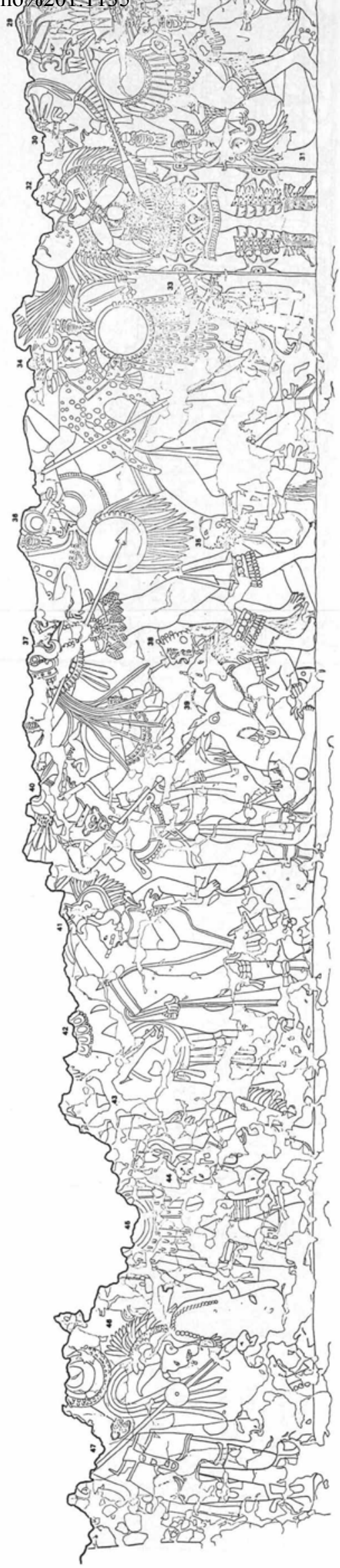




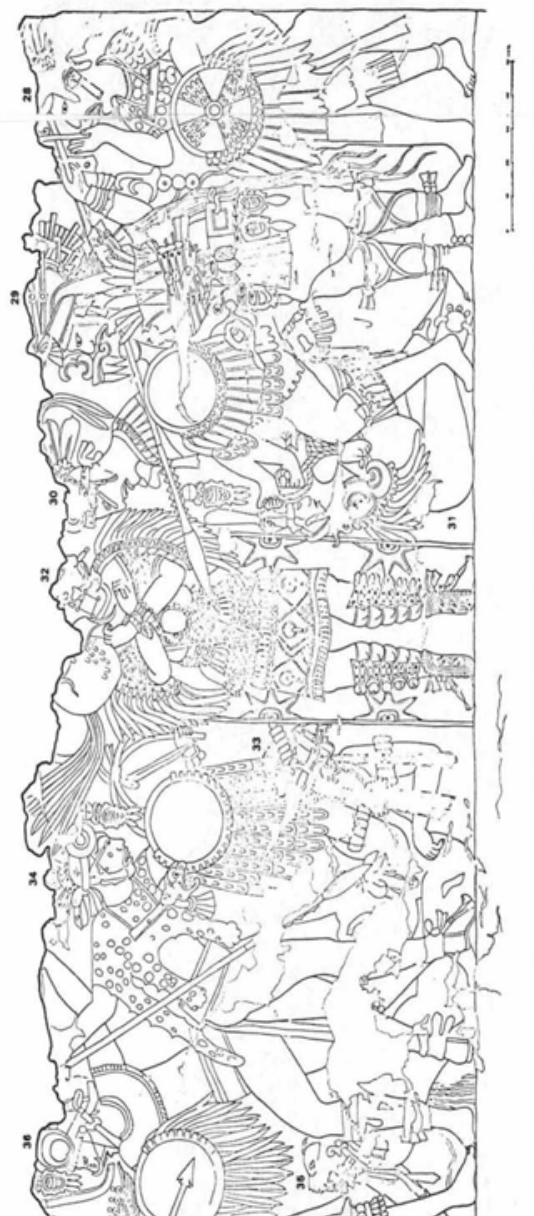




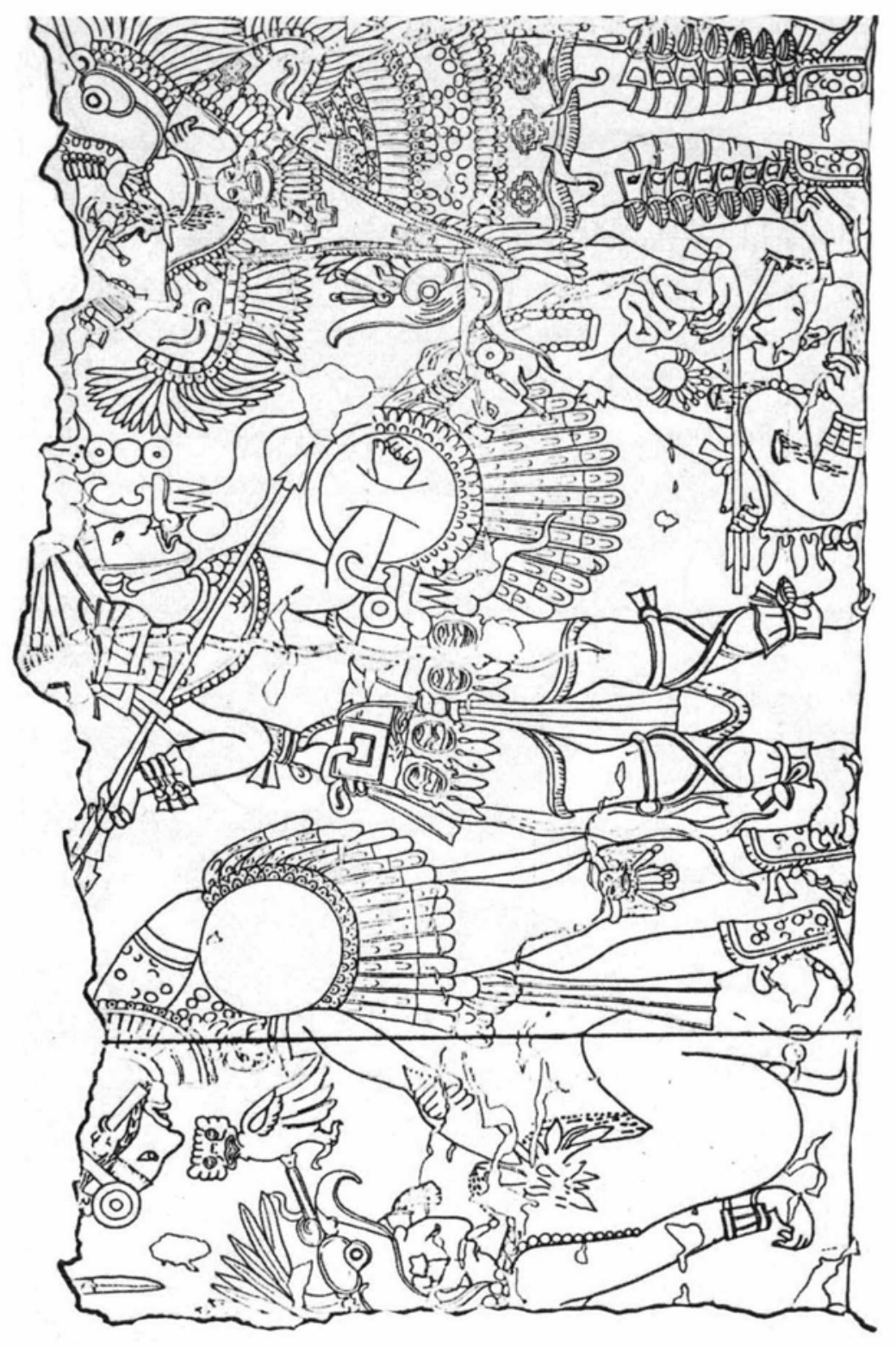

त्ञ 


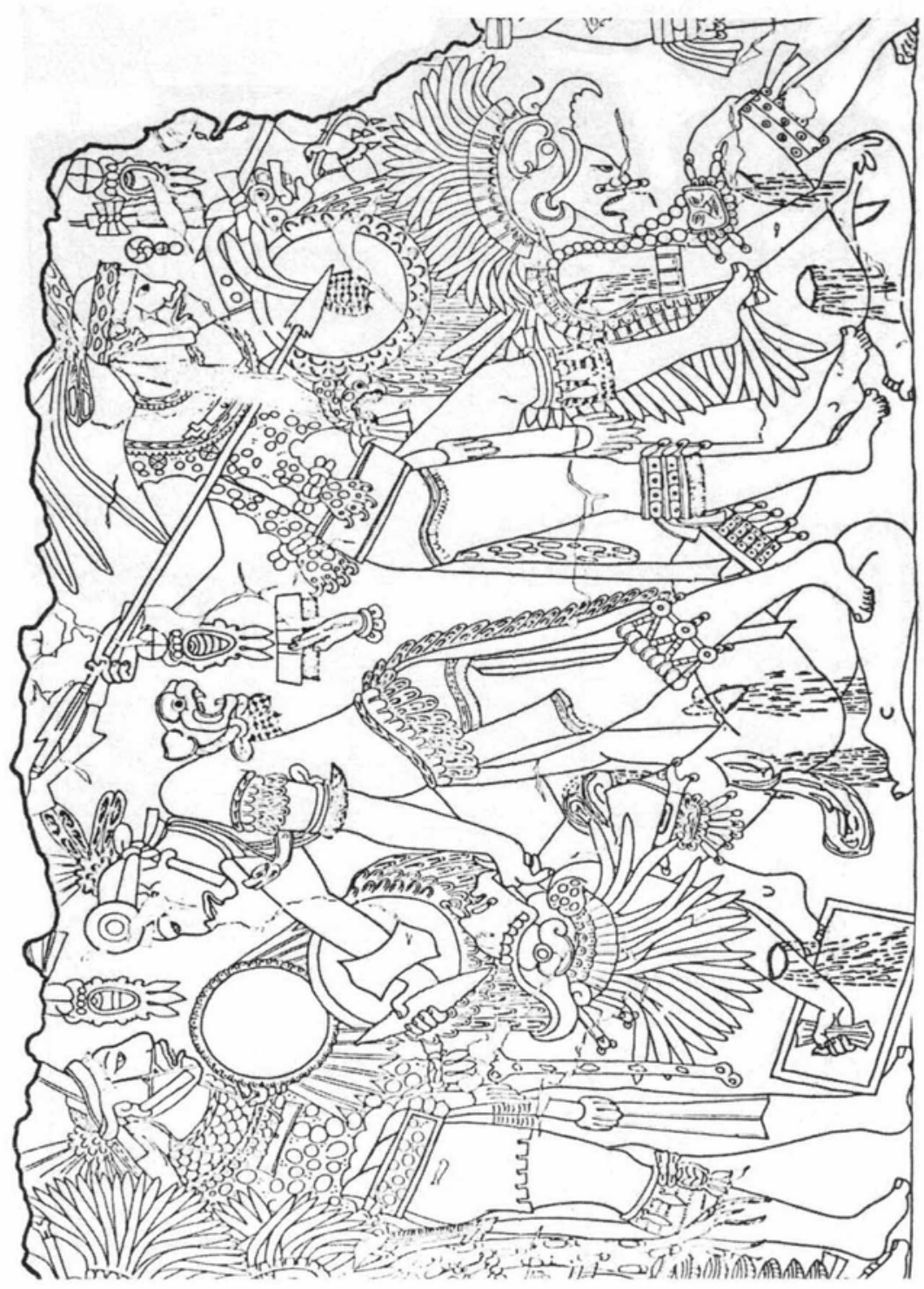




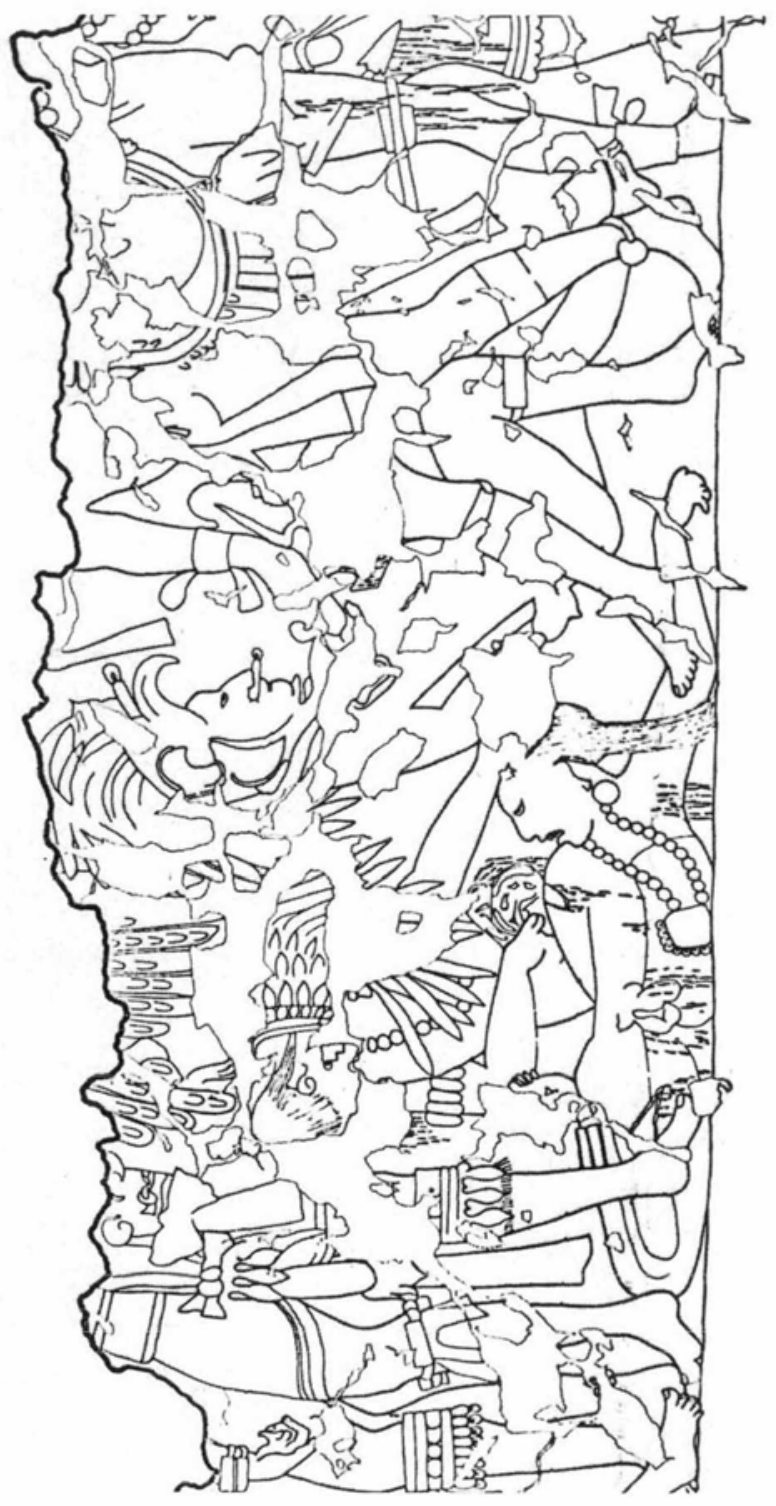

ปั. 


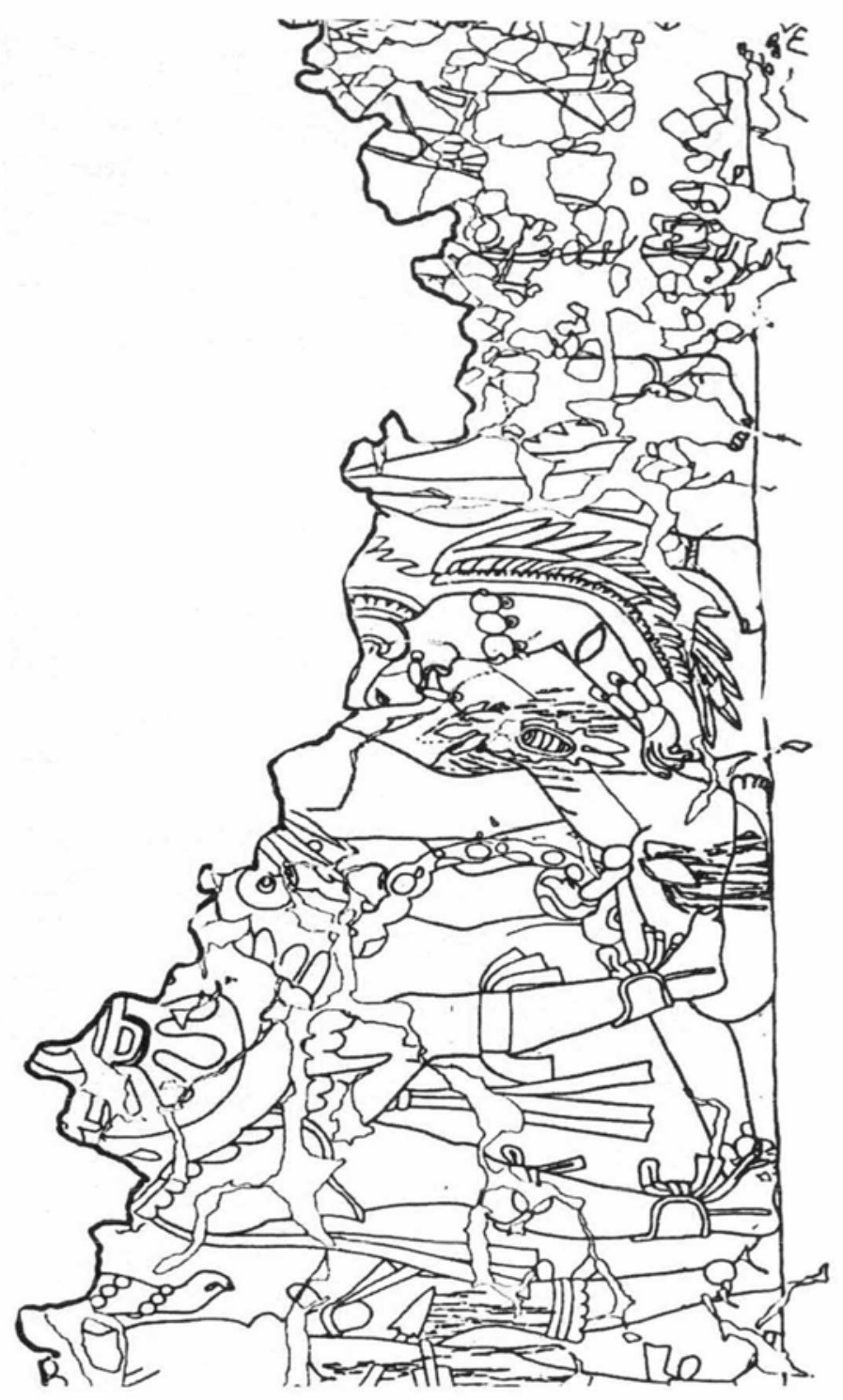


DOI: http://dx.doi.org/10.22201/iie.18703062e.1982.50\%20Tomo\%201.1135

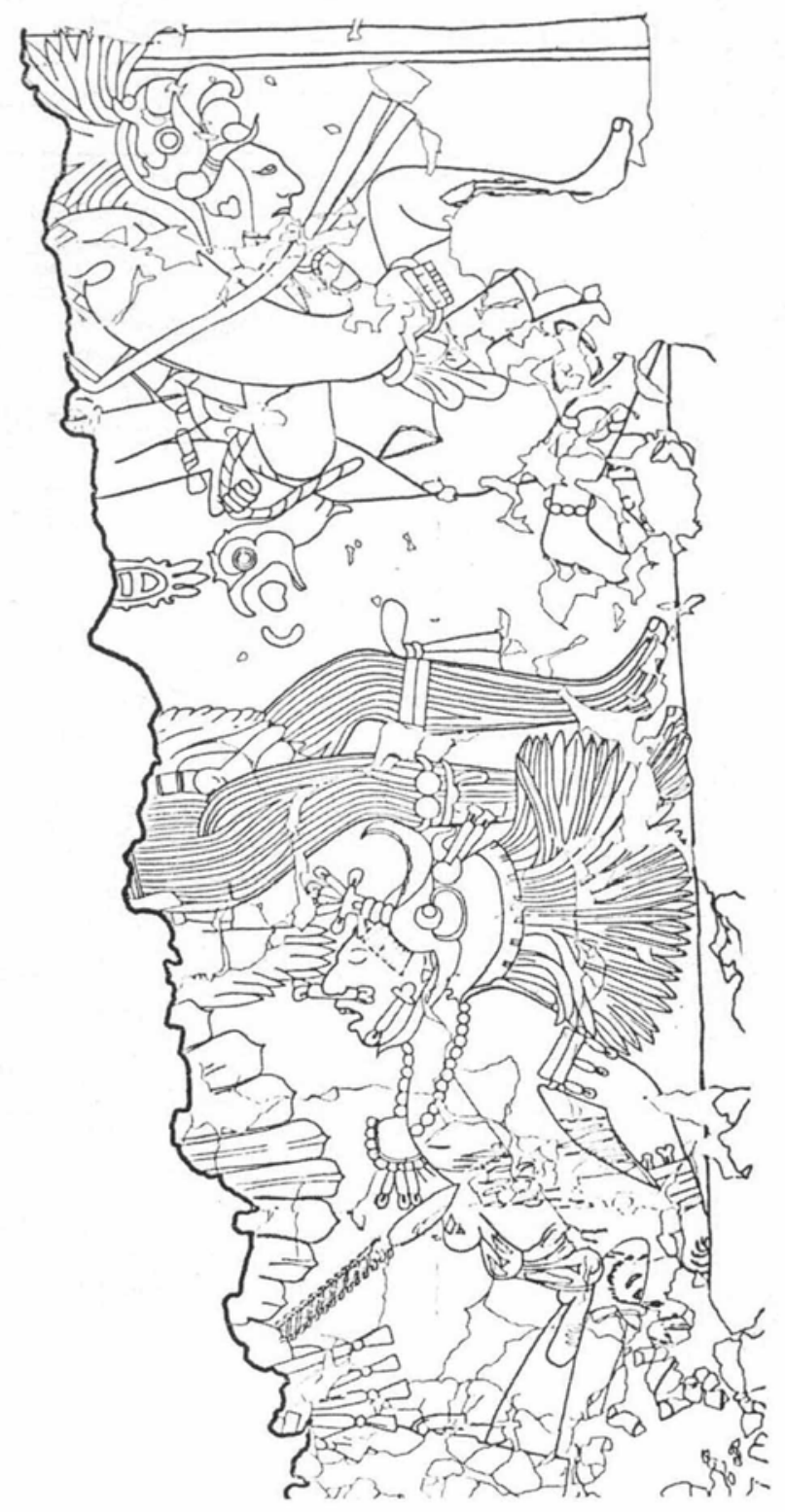

范 


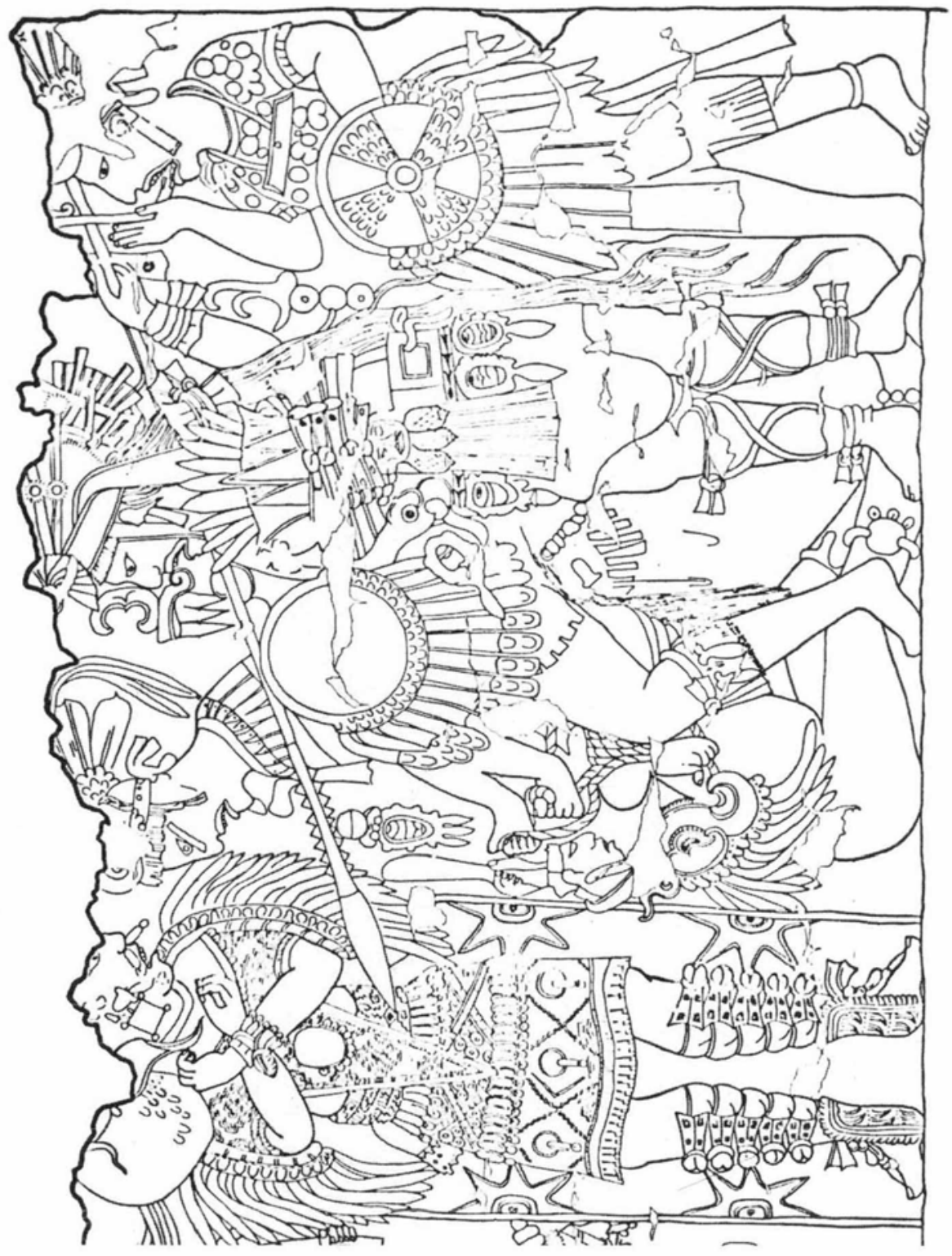

กี่ 


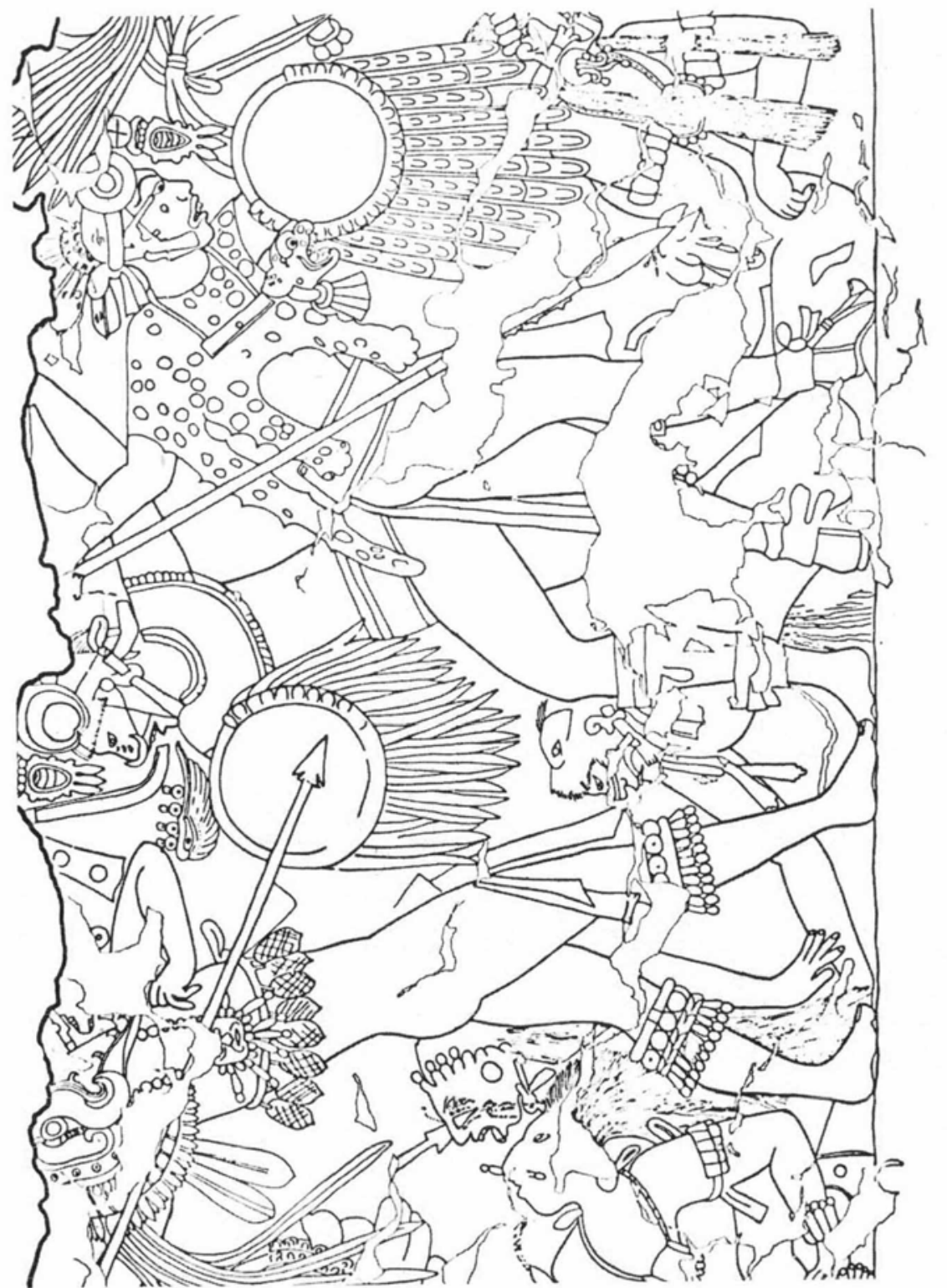

ปే 


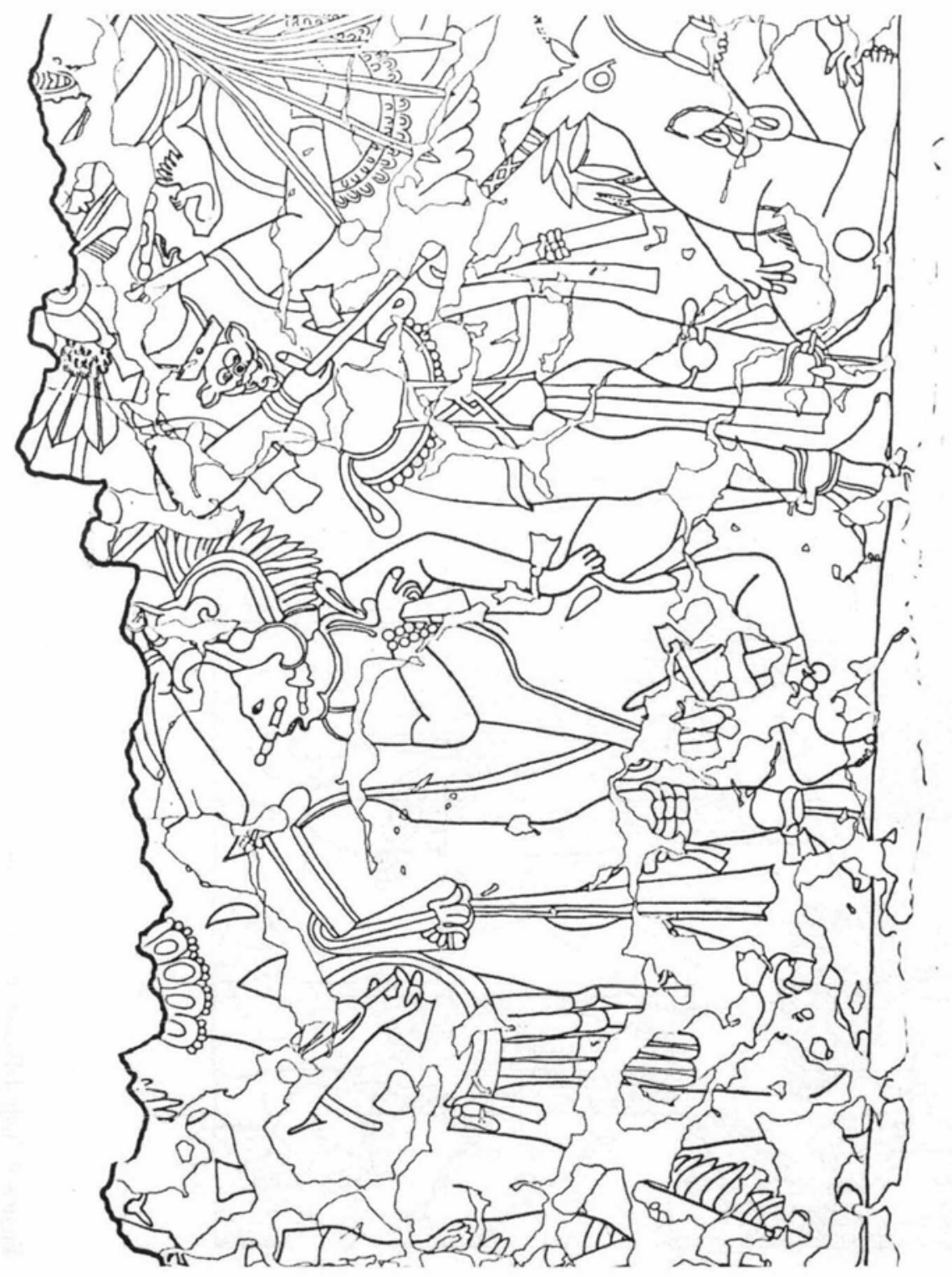

ป气 


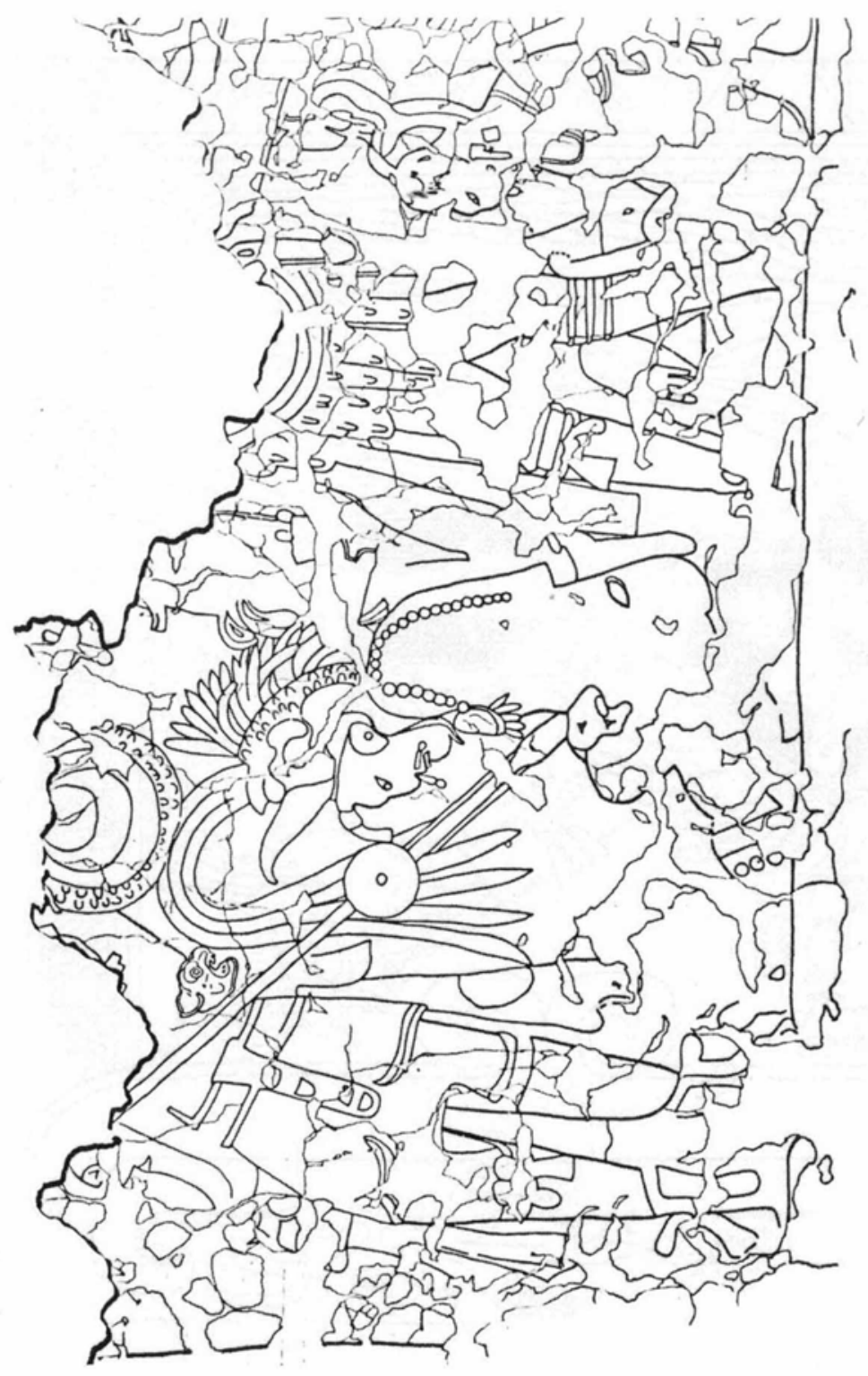

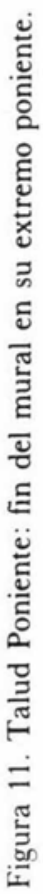


DOI: http://dx.doi.org/10.22201/iie.18703062e.1982.50\%20Tomo\%201.1135

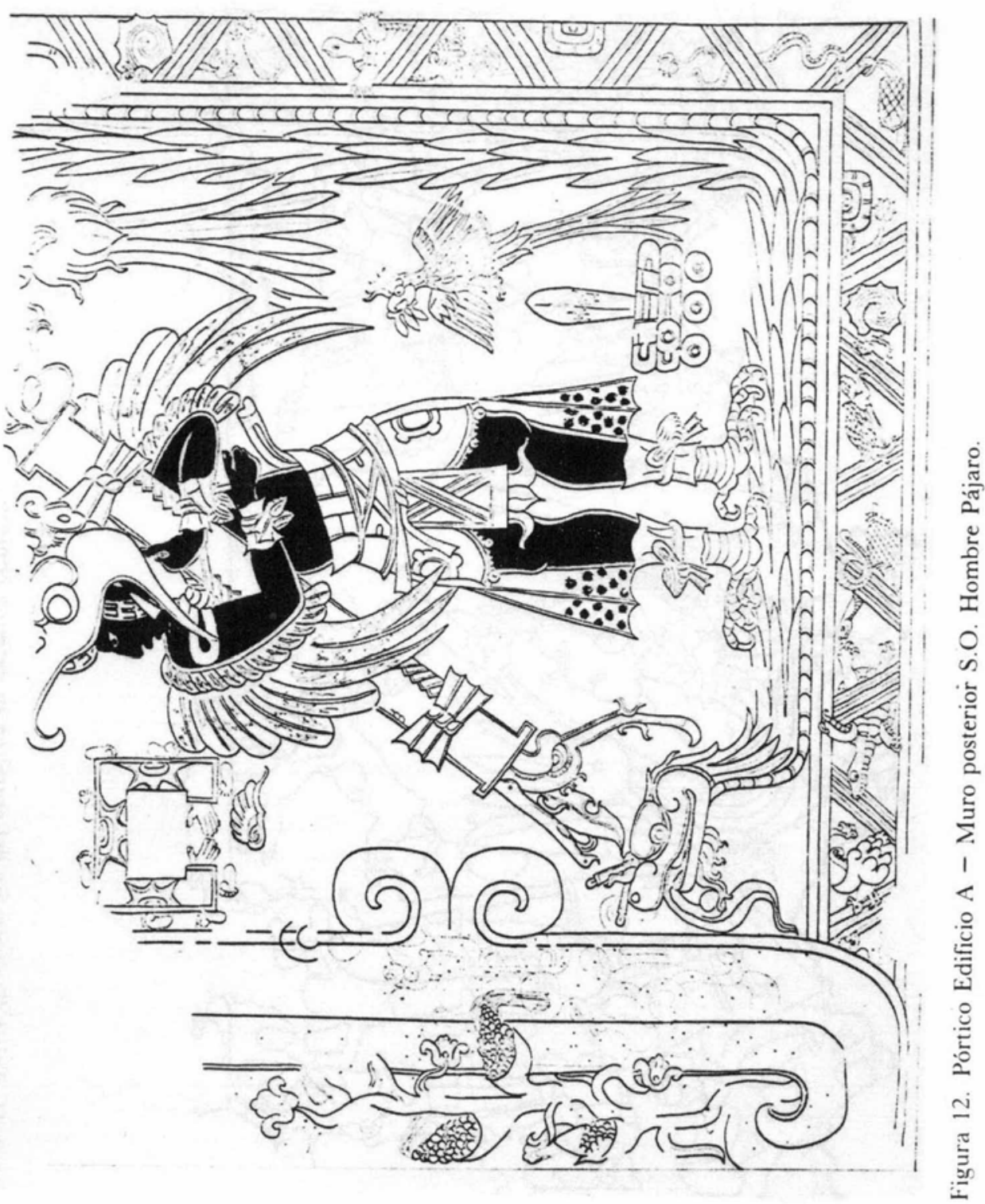




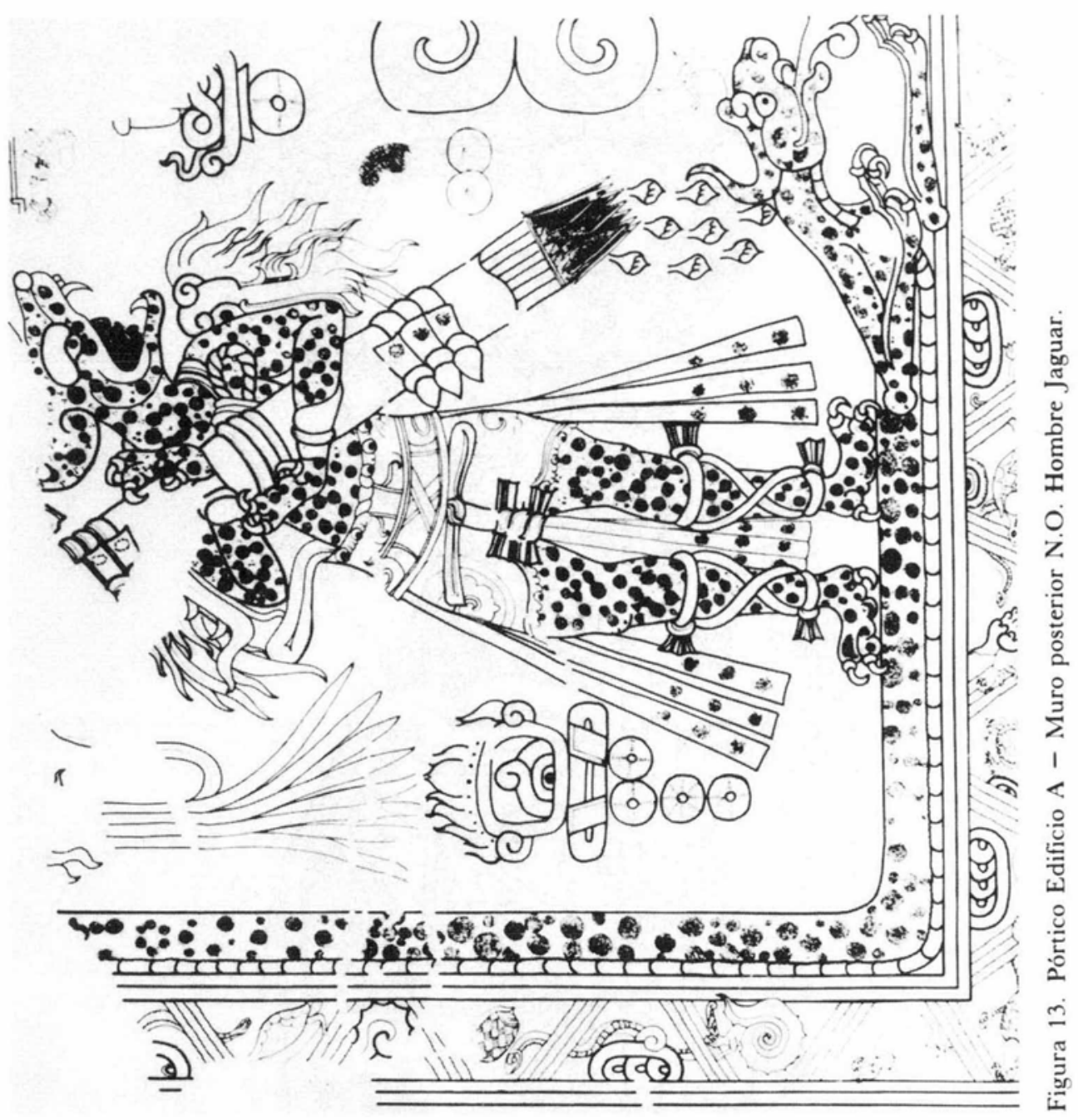




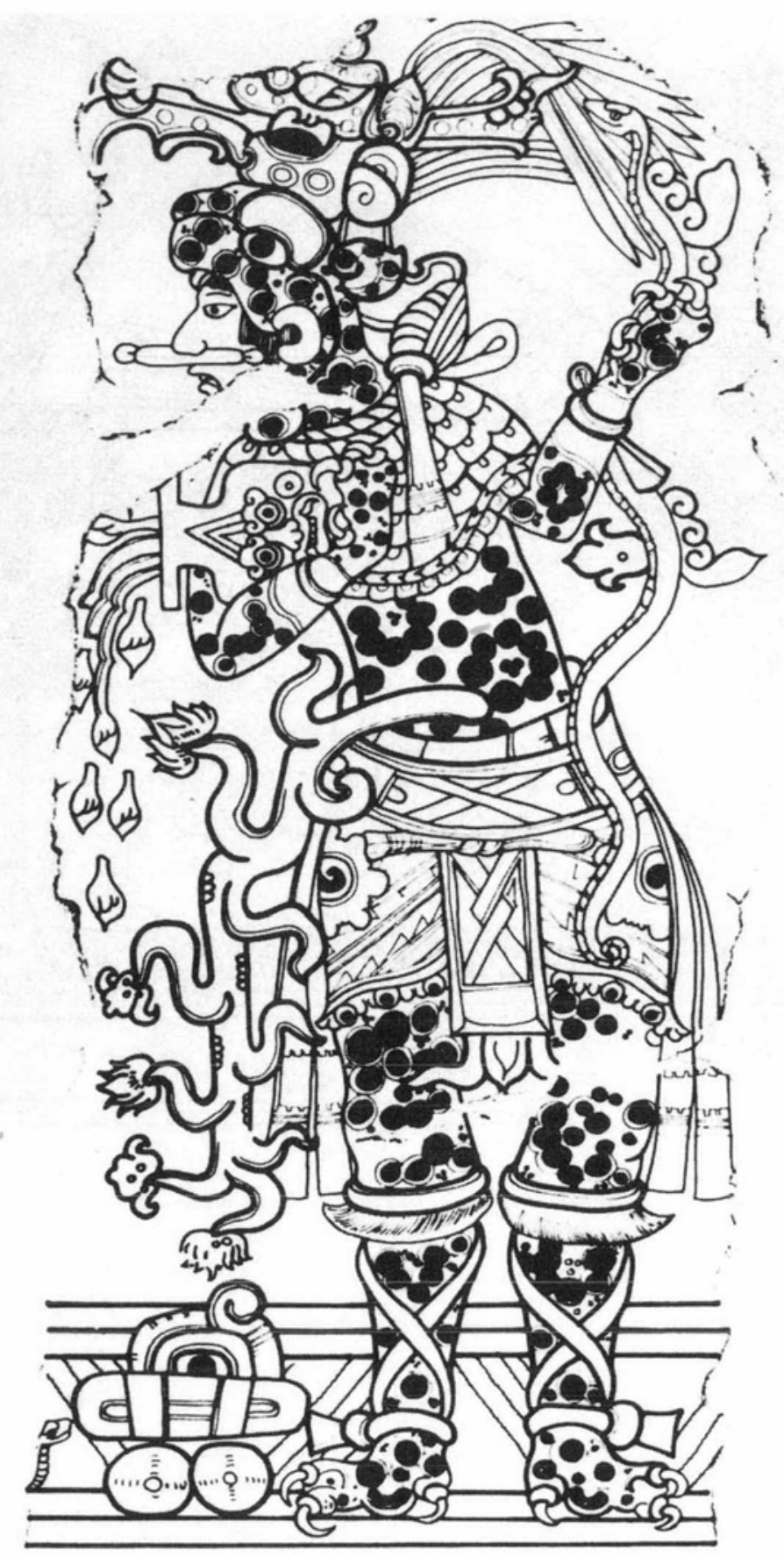

Figura 14. Pórtico Edificio A. Jamba Sur. 


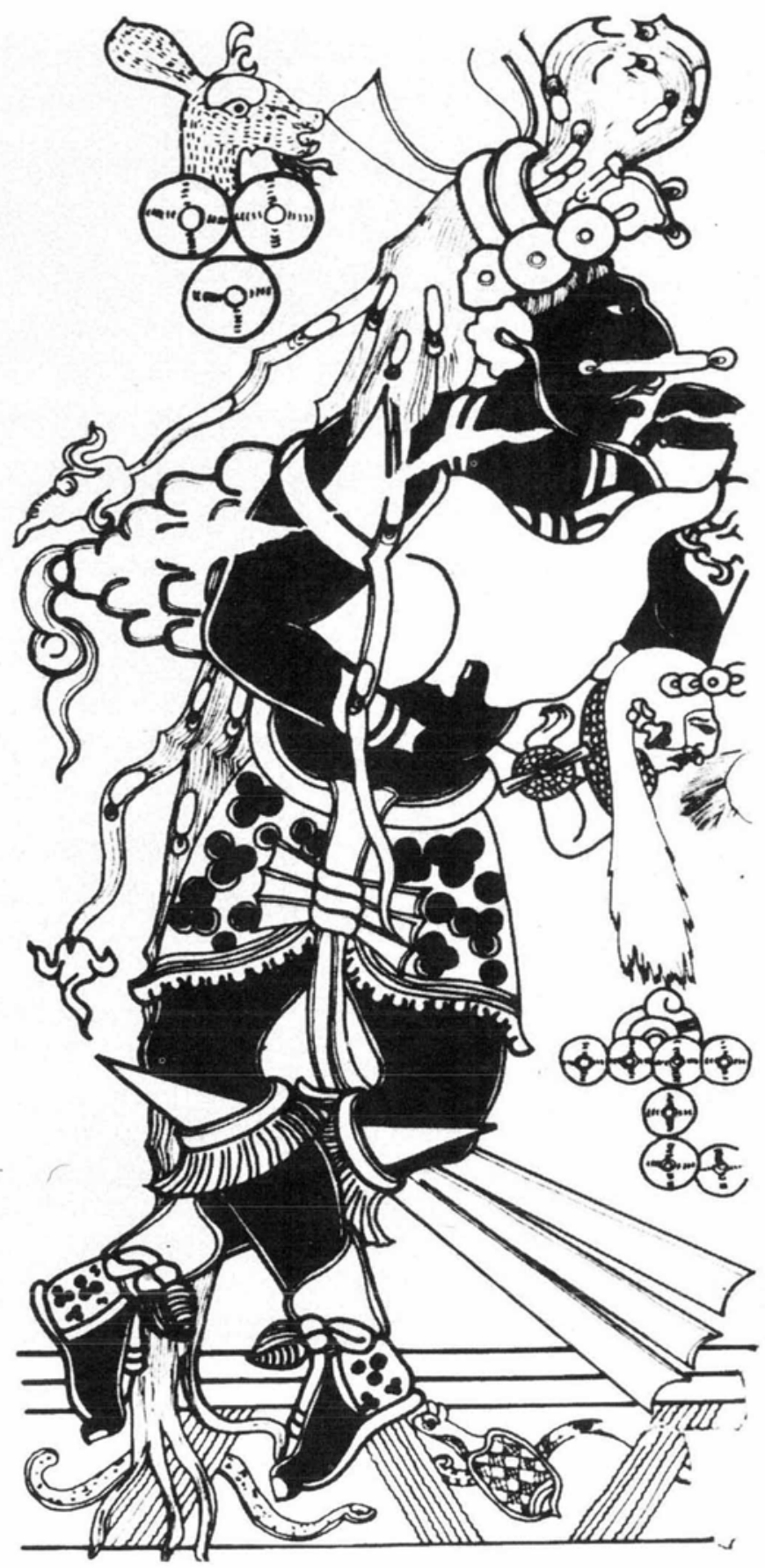

Figura 15. Pórtico Edificio A - Jamba Norte. 


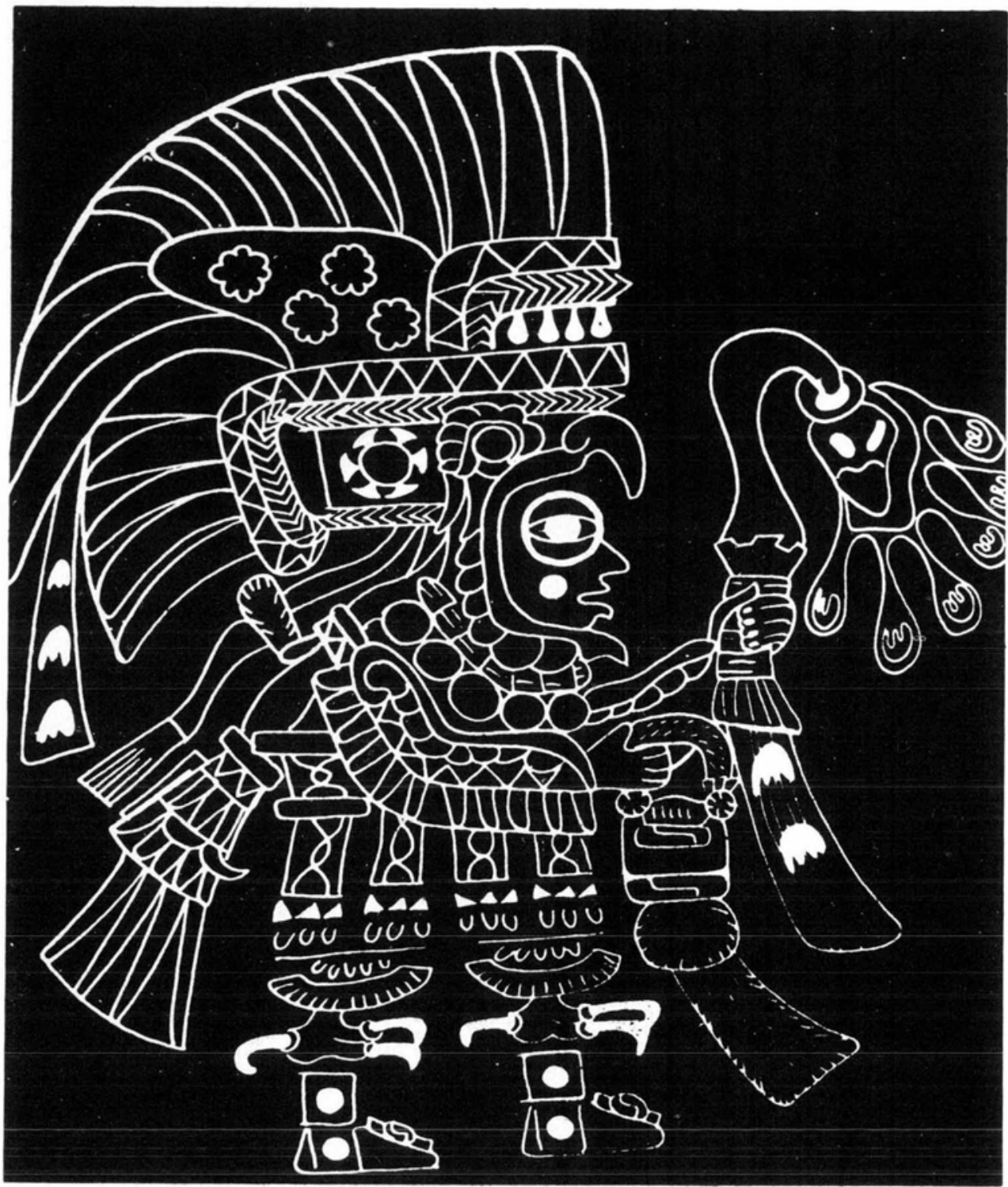

Figura 16. Teotihuacan. Zona 5-A - Glifo "corazón o sangre" en la punta del cuchillo del Hombre Pájaro. 


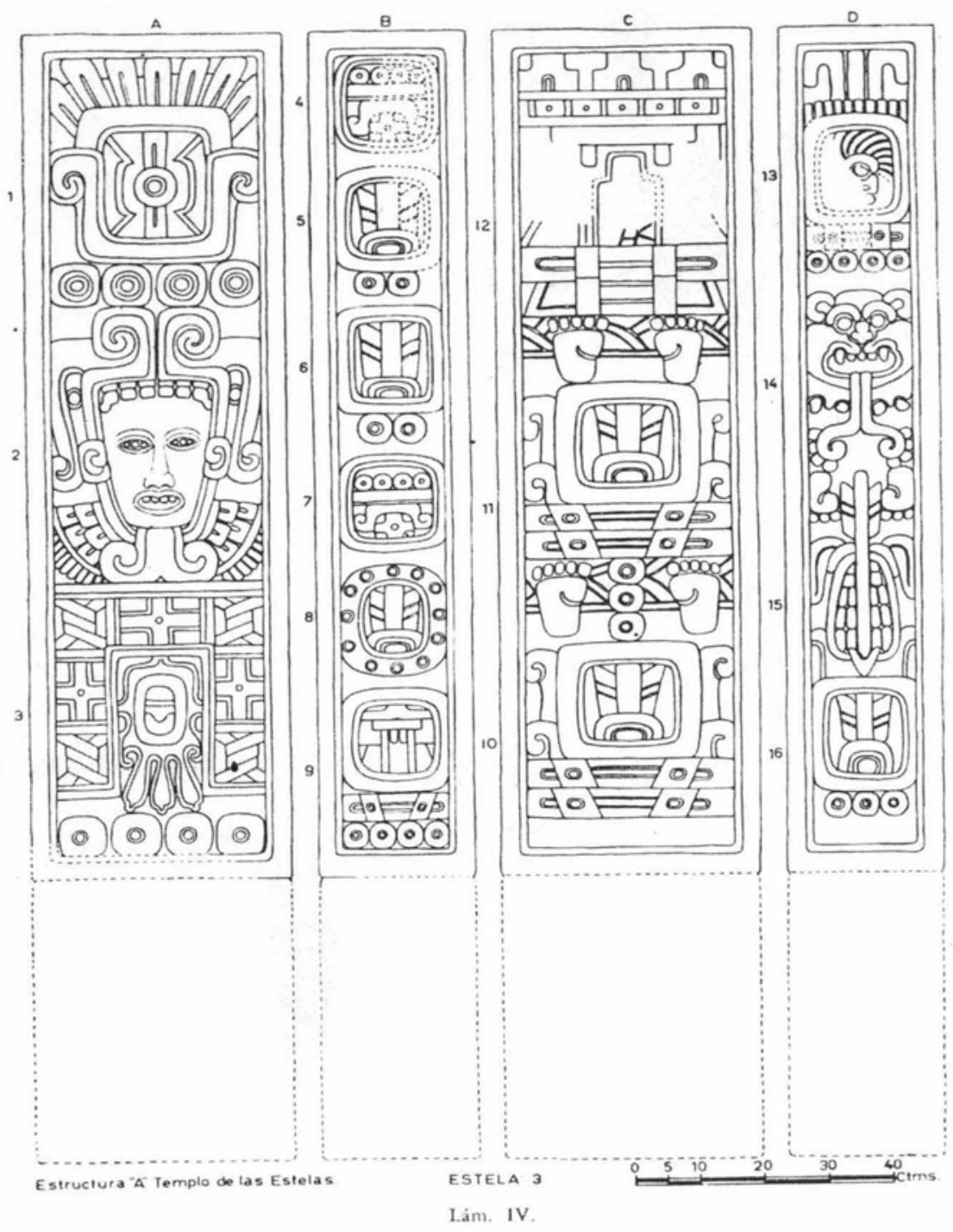

Figura 17. Xochicalco. Estela 3. 


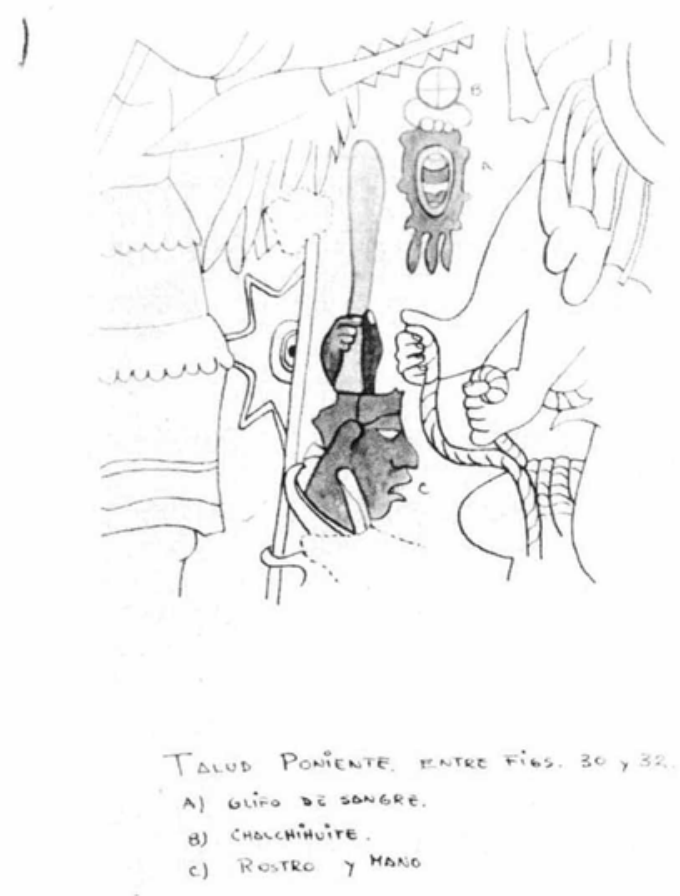

Figura 18. Talud poniente entre personajes 30 y 32 .

Figura 19. Talud de la batalla. Representaciones del glifo "corazón o sangre".
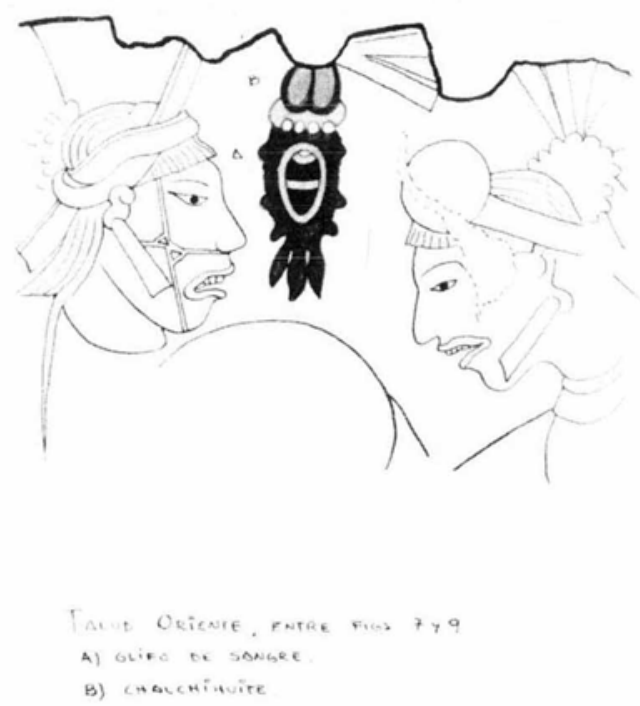


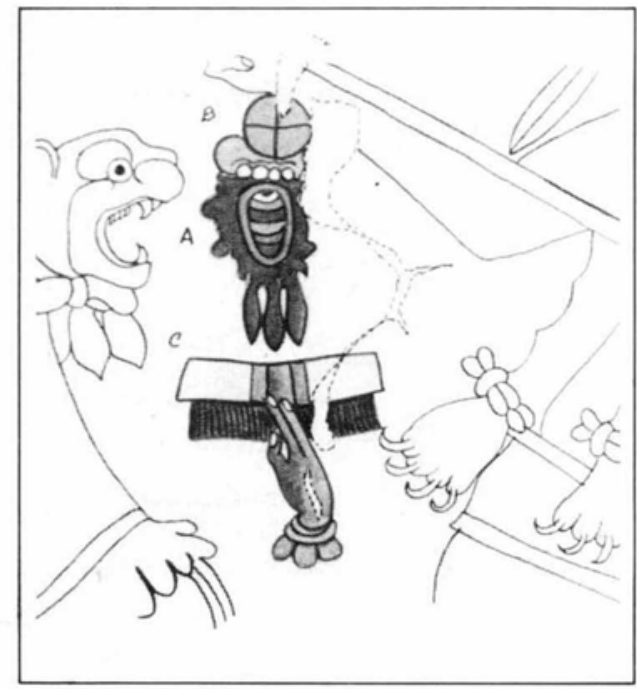

Figura 20. Talud de la batalla. Representa ciones del glifo "corazón o sangre".

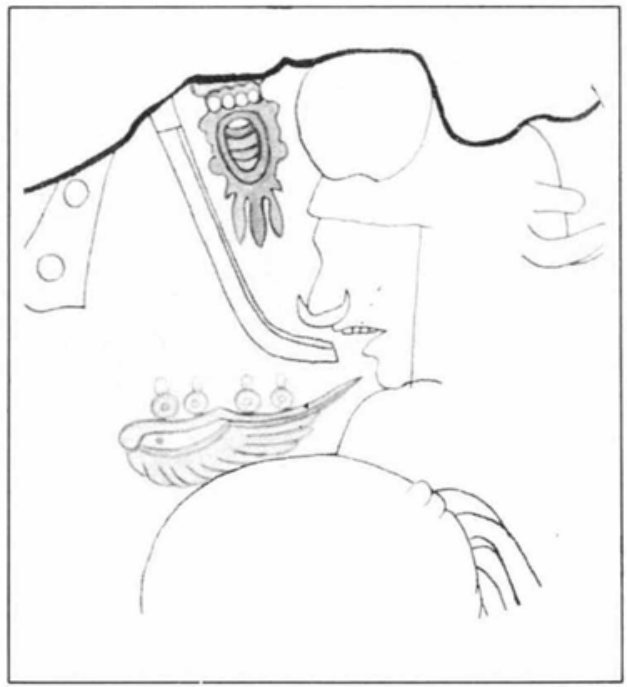

Figura 21. Talud de la batalla. Representa ciones del glifo "corazón o sangre".

Figura 23. Talud Oriente. Glifo corazón o sangre sobre herida en el vientre.

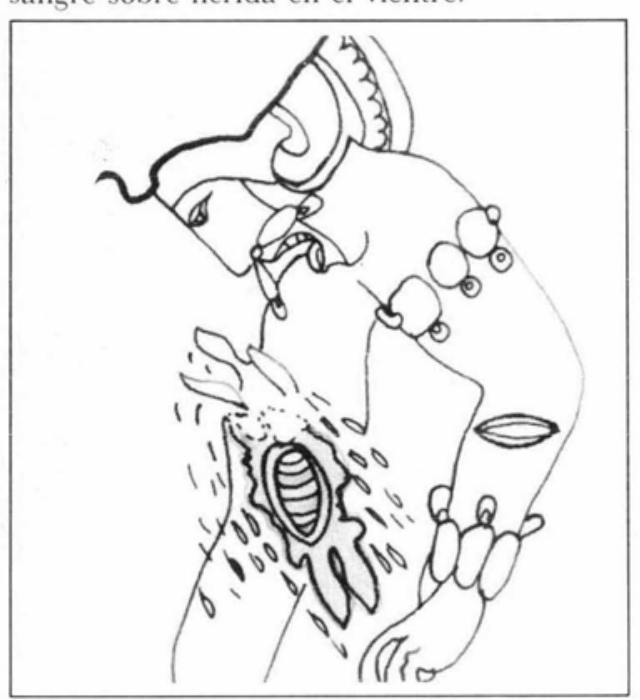

Figura 22. Talud de la batalla. Representa ciones del glifo "corazón o sangre".

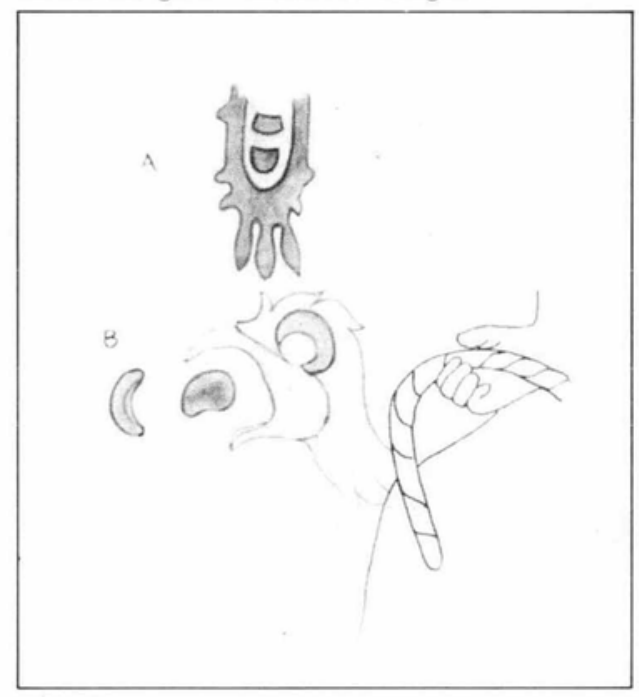




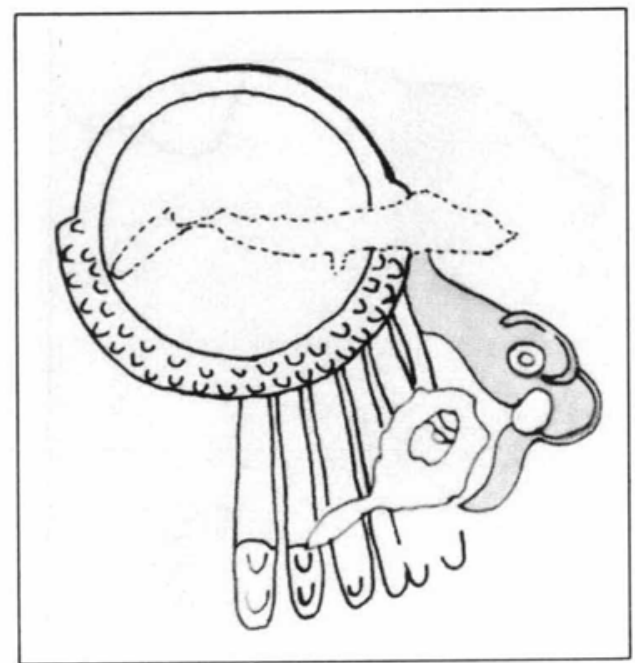

Figura 24. Talud Oriente. Glifo "corazón o sangre" sobre plumas de un escudo.

Figura 25. Talud Oriente. Glifo "corazón o sangre" frente a personaje 10.
Figura 26. Talud Poniente. Glifo "corazón o sangre" y superfijos.

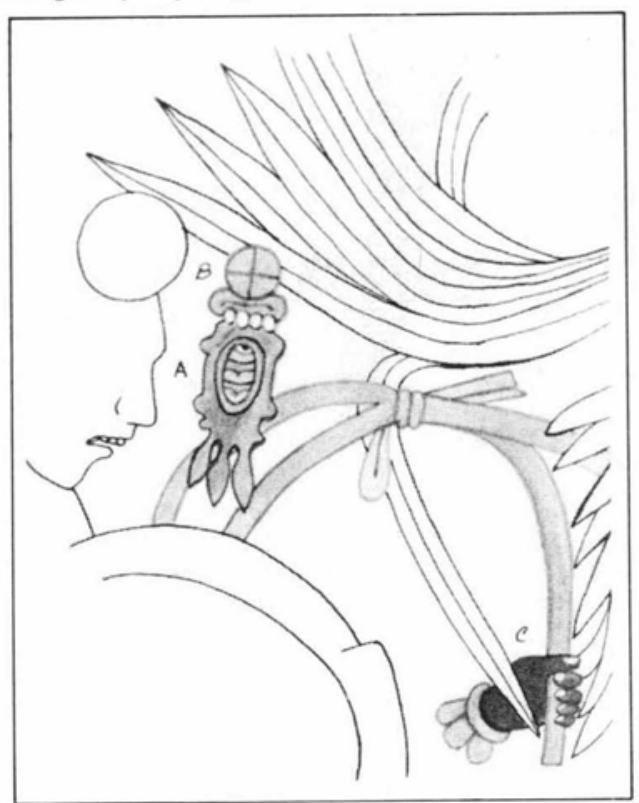

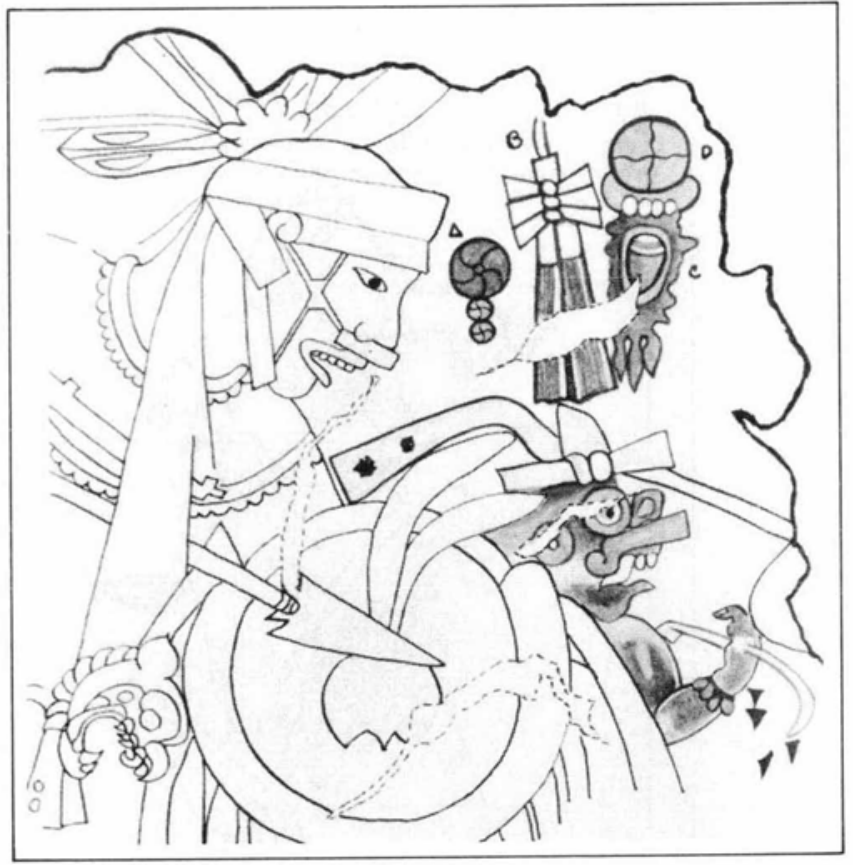




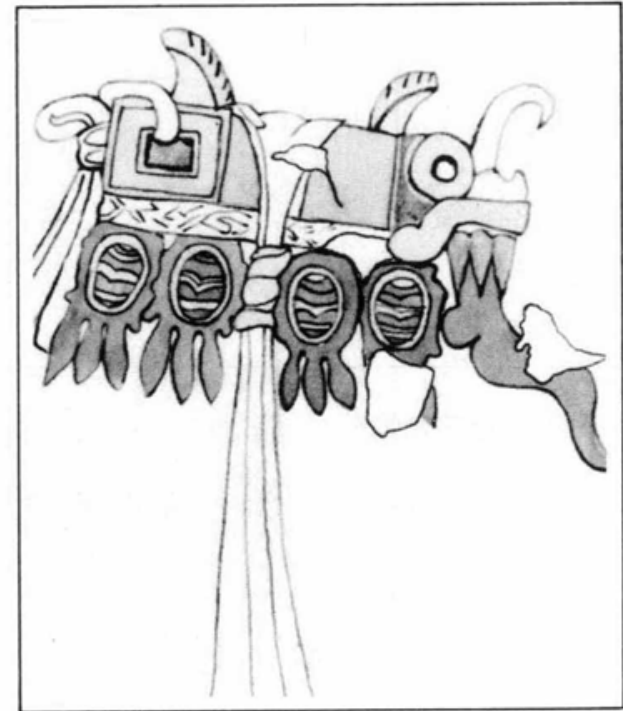

Figura 27. Talud Oriente. Glifo "corazón o sangre" y mascarón de Tláloc en cinturón, personaje 3.

Figura 29. Talud Oriente. Glifo "corazón o sangre" en rodillera personaje 7 .

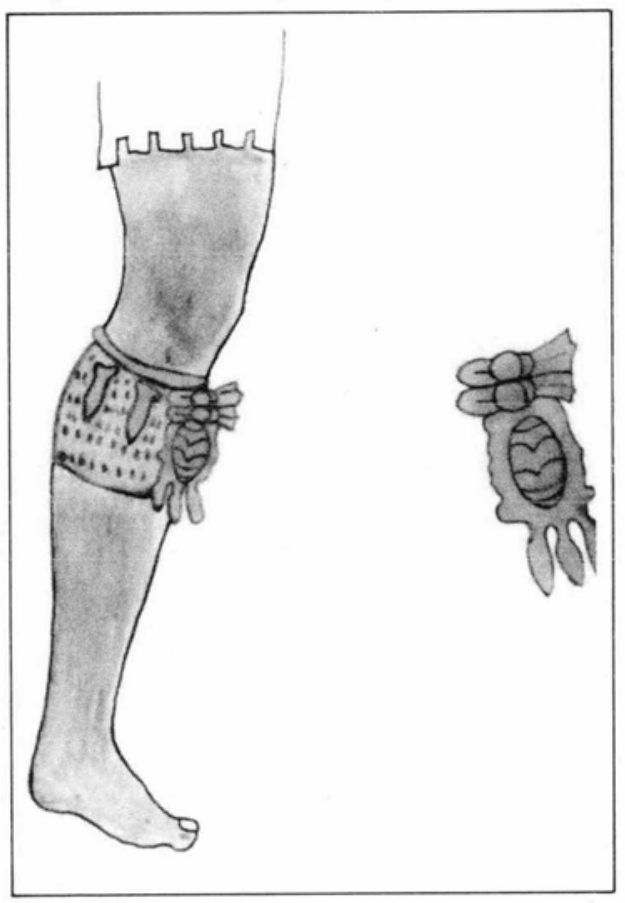

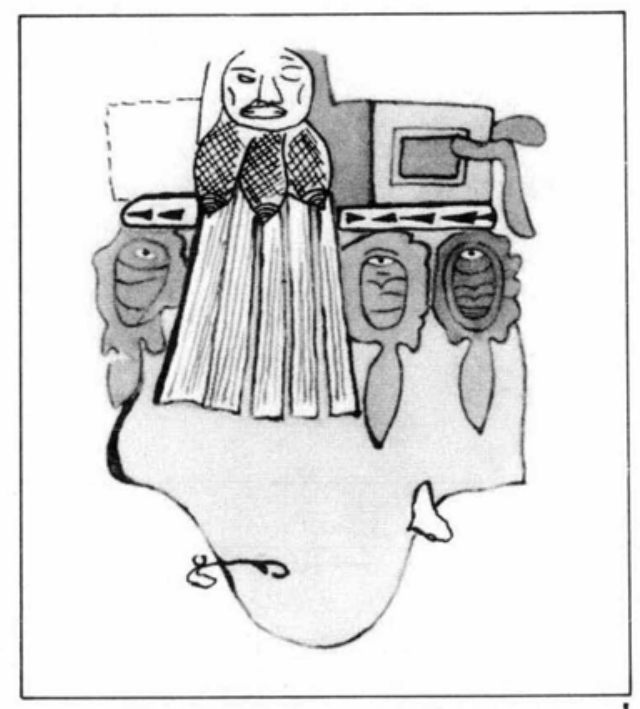

Figura 28. Talud Poniente. Glifo "corazón o sangre" en personaje 29. 
DOI: http://dx.doi.org/10.22201/iie.18703062e.1982.50\%20Tomo\%201.1135

Figura 30. Talud Oriente.

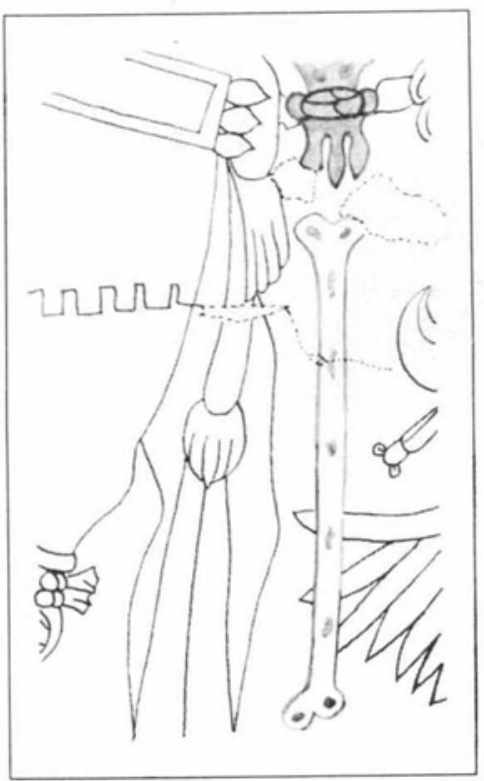

Triple gota de sangre en el remate del chaleco de jaguar del personaje 7.
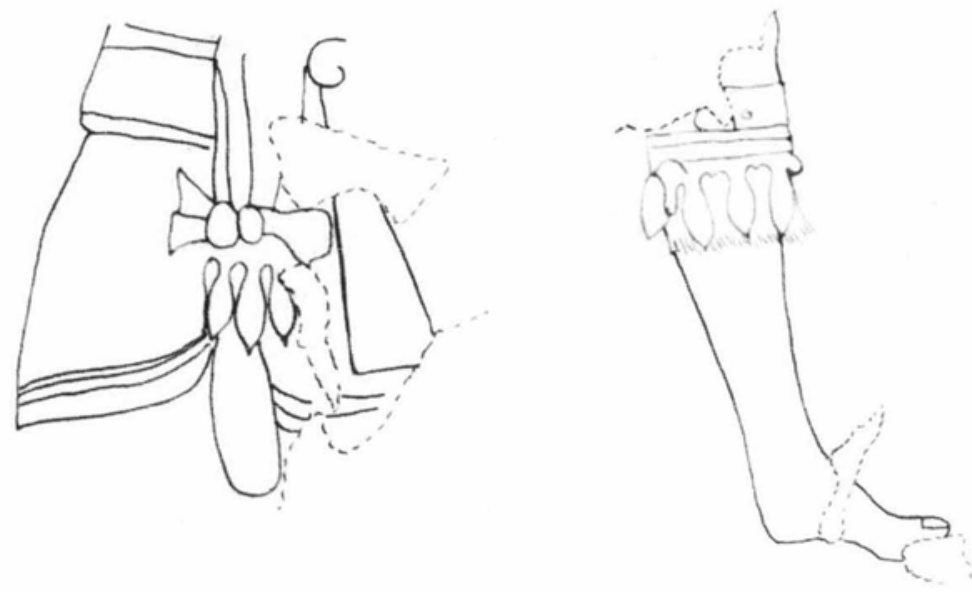

Figura 31. Talud Oriente. Triple gota de sangre en el máxtlatl y gotas de sangre como pendientes en la rodillera del personaje 13. 
DOI: http://dx.doi.org/10.22201/iie.18703062e.1982.50\%20Tomo\%201.1135

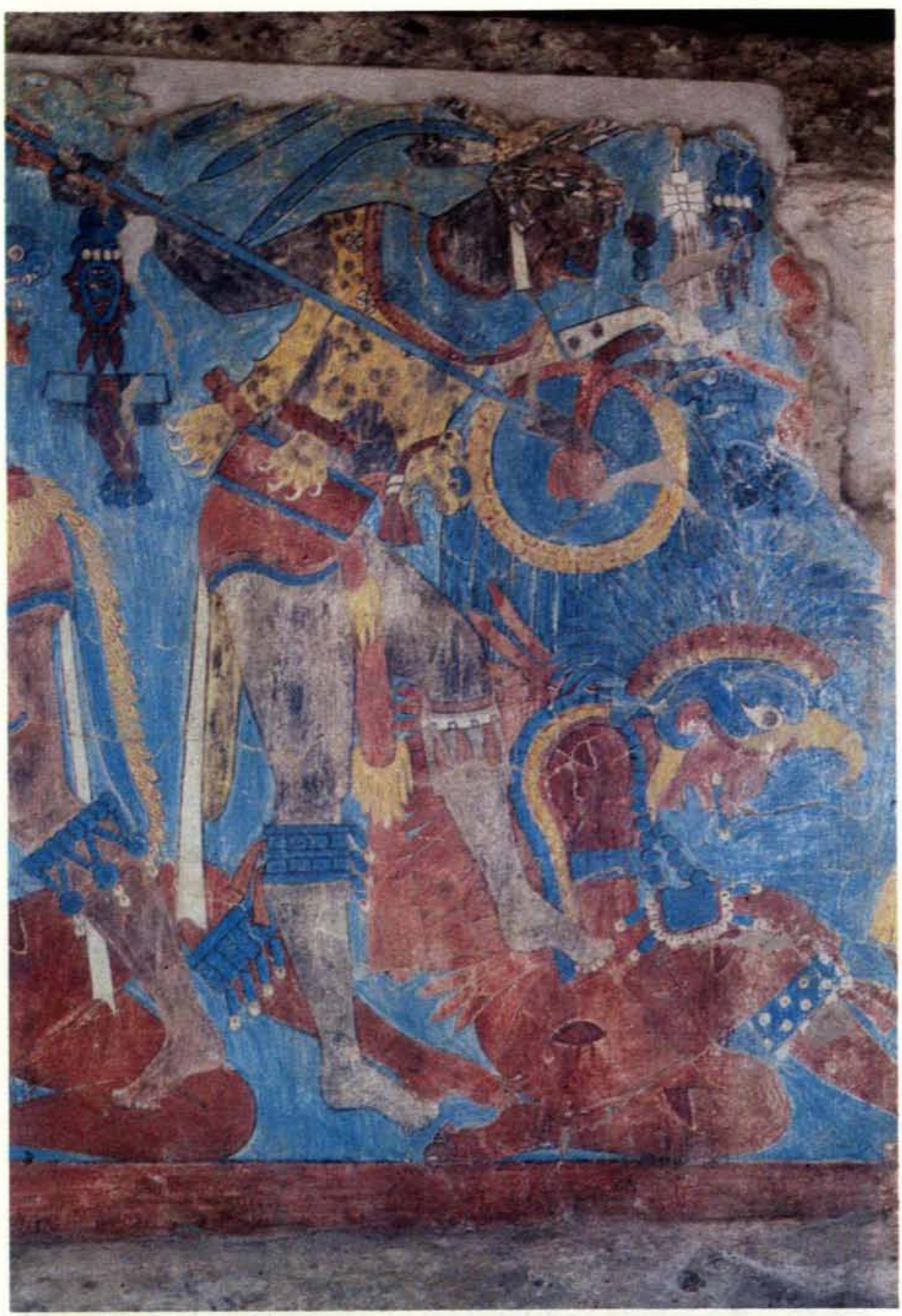

Figura 32. Talud Oriente. Personajes 10 y 11 
DOI: http://dx.doi.org/10.22201/iie.18703062e.1982.50\%20Tomo\%201.1135

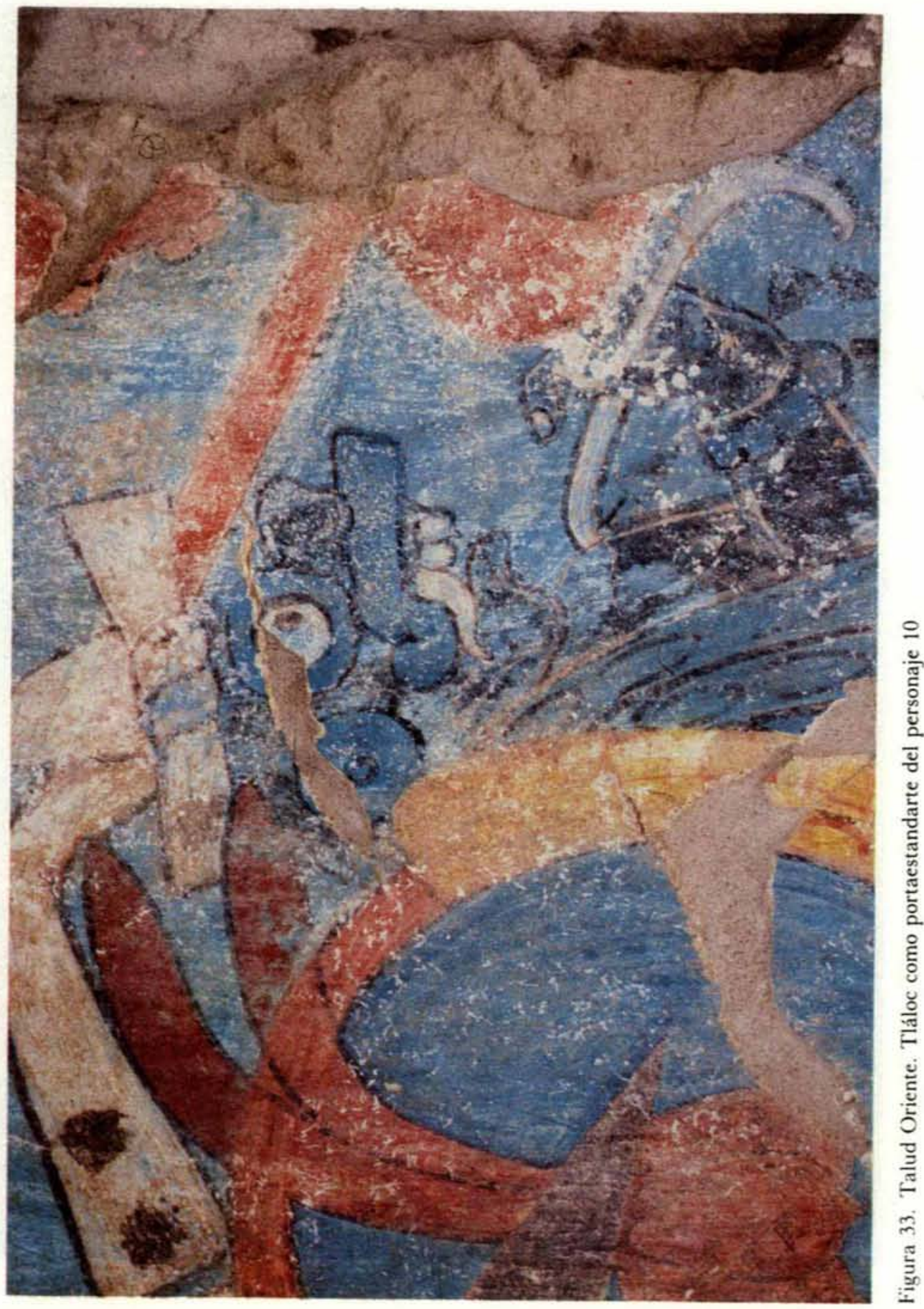


DOI: http://dx.doi.org/10.22201/iie.18703062e.1982.50\%20Tomo\%201.1135

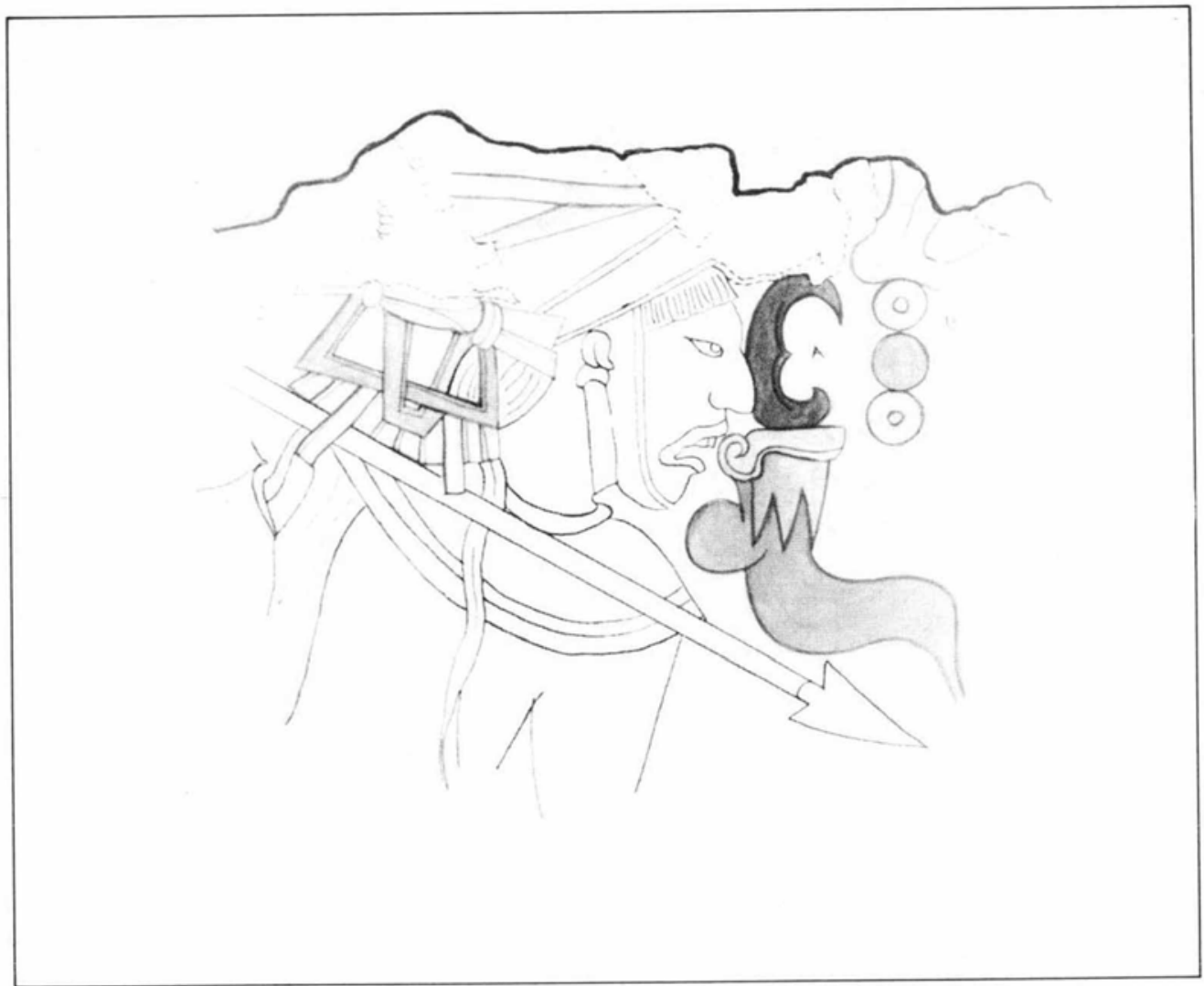

Figura 34. Talud Oriente. Personaje 3. Mascarón bucal y símbolo del año. 
DOI: http://dx.doi.org/10.22201/iie.18703062e.1982.50\%20Tomo\%201.1135

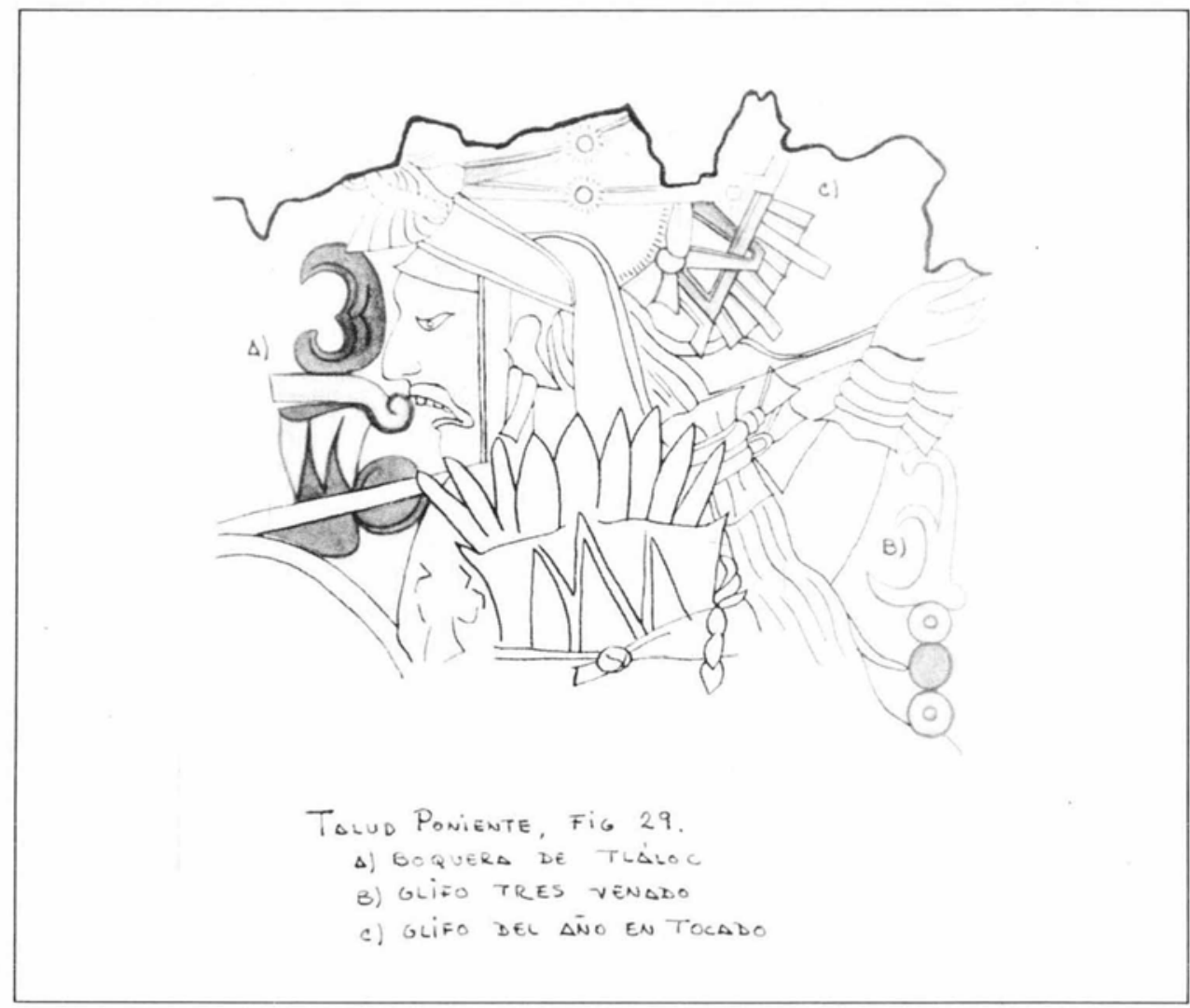

Figura 35. Talud Poniente. Personaje 29. Mascarón bucal y símbolo del año. 
ciones válidas sobre la presencia del espiritu artístico maya en la tradición cultural olmeca xicalanca, tal como fue registrada en el muralismo de $\mathrm{Ca}$ caxtla.

La idea subyacente en este trabajo fue mostrar, de manera sintética y selectiva, el fluctuante movimiento de símbolos y significados relacionados con la iconografía teotihuacana y su difusión espacio temporal, como una muestra significativa de las características del periodo histórico al que pertencen los murales de Cacaxtla 